\title{
LITIGATION AS A MEASURE OF WELL-BEING
}

\author{
Theodore Eisenberg, ${ }^{*}$ Sital Kalantry, ${ }^{* *}$ and Nick Robinson***
}

\section{INTRODUCTION}

In the United States, portraying much litigation as pathological is a key component of business lobbying groups' social construction of the legal system. ${ }^{1}$ These groups commission and use questionable social science analysis ${ }^{2}$ and misleadingly portray highly publicized cases, such as the McDonald's coffee-spill case. ${ }^{3}$ They do so to help characterize civil litigation as dominated by lottery-seeking plaintiffs, greedy plaintiffs' lawyers, and state civil justice systems that are overly hostile to business. Marc Galanter and others have refuted these myths, ${ }^{4}$ but they persist even among well-informed observers. ${ }^{5}$ Debunking misleading litigation anecdotes is both necessary and important. The need to defend against unwarranted attacks on litigation, however, should not distract from studying litigation's important institutional role in society. Notwithstanding the U.S. corporate assault on litigation, law and development scholars have long viewed increased litigation as a natural attribute of increasing prosperity. ${ }^{6}$

* Theordore Eisenberg is the Henry Allen Mark Professor of Law and Adjunct Professor of Statistical Sciences at Cornell University. This Article was presented as the Keynote Lecture at the 2012 Erfurt Conference on Law and Economics.

** Sital Kalantry is the Clinical Professor of Law and Director of the International Human Rights Clinic at the University of Chicago Law School.

*** Nick Robinson is a Visiting Fellow, Centre for Policy Research, New Delhi.

1. See, e.g., William Haltom \& Michael McCann, Distorting the Law: Politics, MeDiA, AND THE Litigation CRISIS (2004).

2. Theodore Eisenberg, The U.S. Chamber of Commerce Liability Survey: Inaccurate, Unfair, and Bad for Business, 6 J. Empirical Legal Stud. 969, 970 (2009).

3. See, e.g., Haltom \& McCANN, supra note 1, at 203-04 \& tbl.6.

4. See, e.g., Marc Galanter, News from Nowhere: The Debased Debate on Civil Justice, 71 Denv. U. L. Rev. 77, 90 (1993).

5. For example, President Obama stated his willingness to consider medical malpractice reform to rein in frivolous lawsuits. President Barack Obama, State of the Union Address (Jan. 25, 2011), available at www.whitehouse.gov/state-of-the-union-2011. The best documented crisis in the medical malpractice field, however, is underclaiming by victim patients. See, e.g., Frank A. Sloan et al., Suing for Medical Malpractice (1993); Paul C. Weiler et al., A MeaSURE OF MALPRACTICE 71-73 (3d. prtg. 1995).

6. See, e.g., Christian Wollschläger, Civil Litigation and Modernization: The Work of the Municipal Courts of Bremen, Germany, in Five Centuries, 1549-1984, 24 LAw AND Soc'y Rev. 261, 261 (1990). 
This empirical study of litigation in India supplies substantial new evidence that higher litigation rates are not necessarily evidence of an overly litigious society or a drain on the economy; in fact, they can be a natural consequence of economic development and improved human well-being. As shown below, more prosperous Indian states have, for decades, had higher litigation rates than less prosperous states. ${ }^{7}$ And, at least in recent years, so have states with higher levels of urbanization. We also report the first evidence that accounting for economic and noneconomic well-being together, as measured by the Human Development Index, seems to explain litigation rate patterns better than explanations limited to only economic measures of wellbeing, such as Gross Domestic Product (GDP) per capita, or only to noneconomic measures, such as literacy rates.

Surprisingly, however, states that have prospered more do not show increased within-state civil litigation rates in recent years. We present evidence that India's enormous case backlog may be deterring potential litigants from filing claims: This raises the question of whether Indian economic growth can be sustained without the well-functioning courts that some regard as an institutional requisite to robust economic performance and human well-being. ${ }^{8}$

Using empirical methodology to focus on both India and litigation rates is particularly appropriate because one reason for this Symposium is to honor Professor Marc Galanter's work. His interest in India's legal system ${ }^{9}$ complements his path-breaking work on the U.S. legal system. He has long used empirical evidence to describe legal systems' operations and held the view that popular opinion about litigation rates in the United States ${ }^{10}$ and India is misplaced. Indians have long been branded as abnormally litigious and Galanter was an early user of data to refute this assertion. ${ }^{11}$ Although comparing stud-

7. See infra Figure 4.

8. For a review of studies of the relation between law and development, see Tom Ginsburg, Does Law Matter for Economic Development? Evidence from East Asia, 34 LAw AND Soc'Y REV. 829 (2000) (book review). On the need for efficient courts to promote well-being, wealth, Justice Without (2010) [hereinafter JUST: RECOMMENDATIONS FOR LEGAL AND INSTITUTIONAL REFORM, at iv 9.

9. See, e.g., Marc Galanter, Law ANd Society in Modern India (1989); MARc GALANTER, COMPETING EQuAlities: LAW AND THE BACKWARd Classes IN INDIA (1984); Marc 202 (1968-1969).

10. See, e.g., Marc Galanter, Real World Torts: An Antidote to Anecdote, 55 MD. L. REv. 1093, 1097-99 (1996).

11. See Marc Galanter \& Jayanth K. Krishnan, "Bread for the Poor": Access to Justice and the Rights of the Needy in India, 55 HAstings L.J. 789, 789-91 (2003-2004). 
ies of litigation rates across countries presents challenges, India's litigation rate appears to be comparatively low, ${ }^{12}$ and may now be even lower than it was in the nineteenth century or the first half of the twentieth century. ${ }^{13}$ We build and extend on this theme of Galanter's work. By emphasizing the relation between civil litigation rates and improved human well-being, we challenge the dogma that increasing litigation rates should be regarded as evidence of a malfunctioning society. ${ }^{14}$

\section{The Relation Between Litigation and Development}

Thoughtful assessments of the relation between litigation rates and economic prosperity have long hypothesized that, at least in early stages of economic development, increasing litigation rates should be associated with increasing economic development. ${ }^{15}$ "Increased reliance on formal law and its processes appears to parallel changes in the complexity of a society which are produced by economic growth and development."16 This parallel-change observation effectively hypothesizes a positive association between litigation rates and prosperity. Professor Galanter's early work on litigation provided information about one possible source of this association. He assembled studies to support the claim that data "from a variety of courts suggest that plaintiffs are predominantly business or governmental units." 17 Economic growth, it is reasonable to assume, manifests itself, in part, in more businesses and more governmental activity and, presumably, greater litigation activity by those entities. The data included studies from Germany and Great Britain, ${ }^{18}$ suggesting that the association is not unique to the United States. in Table 2 of this Article. See infra Table 2.

13. Oliver Mendelsohn, The Pathology of the Indian Legal System, 15 Mod. Asian STud. 823, 849 (1981)

14. Our claims are limited to civil litigation rates. Counterintuitively, high criminal litigation be connected to improved well-being because more economically developed rates might also be con the prosecution of crime more. Frequently, however, higher crimisocieties may institutionalize the prosecution of crime mould nal litigation is also seemingly correlated with higher che details is beyond the scope of this Article.

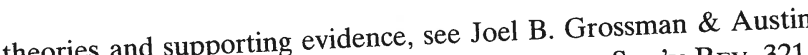

15. For a review of these theories and supporting Perspective, 9 LAw AND SoC'y Rev. 321,

Sarat, Litigation 321-25 (1975).

16. $I d$. at 323 .

17. Marc Galanter, Afterword: Explaining Litigation, 9 LAw AND Soc'y Rev. 347, 348 (1975).

18. Id. at 356 . 
Other data further support the association between economic prosperity and litigation. In 1998, Professor Christian Wollschläger reported on civil litigation rates for thirty-five countries. ${ }^{19}$ Because litigation data were not available for each country for the same year, the data ranged from 1987 to 1996 . He observed that low litigation rates in Ethiopia, Nepal, Paraguay, and the Solomon Islands "can easily be attributed to economic underdevelopment," 20 but he provided no statistical analysis comparing litigation rates with economic development. Data analyzed by Professor Tonja Jacobi about U.S. states detected a positive association between litigation rates and a strong economy, which led her to "challenge[] the claim that litigation is a burden on the U.S. economy that prevents its efficient operation." 21 Professor David Clark's study of regions within six countries (Chile, Columbia, Costa Rica, Italy, Peru, and Spain) found that "there is a positive relationship between elevated socioeconomic development and higher rates of civil litigation."22 Professors Tom Ginsburg and Glenn Hoetker found that greater economic activity was marginally significantly associated with increased filings per capita in Japan. ${ }^{23}$ There may be limits to this positive relation, in that it may be strong in relatively early stages of economic development and later level off. Data from England was offered to support this hypothesis ${ }^{24}$ and within-country differences in economic development in Spain were associated with expected variation in litigation rates. ${ }^{25}$

Professor Galanter has noted that assertions of excessive litigiousness have some troubling roots in anti-Semitism. ${ }^{26}$ But even the stere-

19. Christian Wollschläger, Exploring Global Landscapes of Litigation Rates, in SozIOLOGIE DES ReChTS: FetsCHRIFT FÚR ERHARd BLANKENBURG 577, 582 (1998)

20. Id. at 582-83.

21. Tonja Jacobi, The Role of Politics and Economics in Explaining Variation in Litigation Rates in the U.S. States, 38 J. Legal STUd. 205, 206 (2009). Data covering mid-twentieth century U.S. states' economic growth and litigation rates did not fit the expected pattern, but the findings are limited by having considered only the tiny fraction of U.S. litigation brought in federal courts. See Grossman \& Sarat, supra note 15, at 342 . Jacobi used state court data and noted their numerical dominance. See Jacobi, supra, at 219-20.

22. David S. Clark, Civil Litigation Trends in Europe and Latin America Since 1945: The Advantage of Intracountry Comparisons, 24 LAw AND Soc'y REv. 549, 557 (1990).

23. Tom Ginsburg \& Glenn Hoetker, The Unreluctant Litigant? An Empirical Analysis of Jacoefficient for per capita 35 J. LEGAL STUD. 31, 48-51 (2006). The authors report a regression as marginally statistically significant was significant at the $\mathrm{p}=0.10$ level, which is often described were associated with increased litigation. Id.

24. Grossman \& Sarat, supra note 15, at 324 (citing Lawrence Friedman's analysis of data from England).

25. Id. (citing Jose Toharia's analysis of intracountry data from Spain).

26. Marc Galanter, The Conniving Claimant: Changing Images of Misuse of Legal Remedies, 50 DePaul L. Rev. 647, 649 (2000) ("When faking [of claims] flourished in the early years of 
otype that Jews are more likely to be plaintiffs can simply be seen to reflect the association between economic well-being and litigation. In 2000 , Galanter noted that economic reasons explained why Jewish residents of the Detroit metropolitan area in 1967 were more likely than others to go to lawyers. ${ }^{27}$ Economic prosperity was offered as a rational alternative explanation to not-so-thinly veiled bigotry.

Litigation rates, of course, are not merely a function of economic activity. Different dispute resolution institutions can lead two economically similar countries to have quite different litigation rates. ${ }^{28}$ Indeed, Professor Clark suggested that within-country comparisons country comparisons. ${ }^{29}$ Within a country, Professors Ginsburg and Hoetker showed that institutional changes in Japan-expansion of the bar, procedural reform, and an increase in the ${ }^{2}$, prefectures. ${ }^{30}$ Prowere associated with litigation the political factors, such as the divifessor Jacobi reporter between political parties, are associated with sion of state pow litigation rates. ${ }^{31}$ We therefore include in our analysis of litigation rates important noneconomic factors for which information is available-noneconomic measures of well-being, urbanization, and litigation delay.

Our study complements two prior studies of Indian litigation. Menaka Guruswamy and Aditya Singh reported information about India's state-level litigation rates and state-level measures of well-being. ${ }^{32}$ They studied states' case filings for one year, from July 1, 2008 to June 30,2009 , and informally compared them with state-level poverty rates, literacy rates, and violence. ${ }^{33}$ They observed a positive association between lower poverty rates, as measured in 2004-2005, and civil case filing rates in 2008-2009.34 They also observed a positive

the Twentieth Century, it was often associated in the public mind with Jews." (citing Ken DornMaking of a Personal Injury Underworld in stein, Accidentally on Purpose: The Making

AMERICA 60 (1996))).
27. Id. at 653 n.20 ("Silverman attributed greater Jewish involvement with

greater wealth and social integration than to religious or Civil Litigation: Comparing Cultures

28. Erhard Blankenburg, The Infrastructure for Avormany, 28 LAw AND Soc'y Rev. 789, 789

of Legal Behavior in the Netherlands and West Germany, institutions filtering disputes).

(1994) (finding different litigation rates based

29. See Clark, supra note 22 , at 565-66. 23 at $49-50$.

30. See Ginsburg \& Hoetker, supra note

31. See Jacobi, supra note 21, at 222.

32. Menaka Guruswamy \& Aditya Singh, Vill 281, 282 (2010).

with Unjust Outcom

34. Id. at 286. 
association between higher literacy rates, as reported in the 2001 Census, and civil filing rates, and a similar association between Naxalite violence $^{35}$ reported in 2008 and civil filing rates. ${ }^{36}$ Professors Arnab Kumar Hazra and Maja Micevska studied state-level court congestion from 1995 to 1999 by assessing, among other factors, civil caseloads per capita and civil caseloads per judge. ${ }^{37}$ They found a negative association between these caseload measures and state GDP per capita. ${ }^{38}$ They attributed the negative association to the fact that states with greater resources are able to clear cases at a higher rate. ${ }^{39}$

We extend Guruswamy and Singh's findings by focusing on additional factors affecting litigation, by analyzing more years of data, and by using statistical methods to test the likelihood of the observed relations occurring by chance. Our study differs from Hazra and Micevska's work because we studied the litigation rates that focus on new filings, whereas their caseload measures included pending cases. Additional resources, as measured by GDP, may help process existing cases, but need not similarly affect new case filing rates.

Part III of this Article briefly describes India's legal system. Part IV describes our hypotheses and the data we analyze. Part V presents results on the relation between economic and other measures of wellbeing and litigation rates. Part VI discusses the results and concludes.

\section{BACKGRound of India's Legal System}

India consists of twenty-eight states and seven union territories. 40 Figure 1 shows the states and territories; the shading provides a summary of the civil filing and GDP data presented in more detail in Part V.

35. Id. Naxalite is briefly described as follows:

Today, the peasant uprising that brought the word "Naxalite" to the lips of common people is forty years old. Naxalbari, where this peasant insurrection was born and subsequently entered into the national consciousness, is still a sleepy, quiet town in north Bengal. Although the revolution is over, and policemen are still killed either by bomb blasts or mines, and government officials are kidnapped for heavy ransom.

Arnab Kumar Hazra \& Maja B. Micevska, The Problem of Court Congestion: Evidence from Indian Lower Courts, Judicial Reforms In India: Issues \& Aspects 137, 144-45 (Arnab Kumar Hazra \& Bibek Debroy eds., 2007) [hereinafter Judicial Reforms in INDiA].

36. Guruswamy \& Singh, supra note 32 , at 287. See Jayanta Mahapatra, Comment: Letter from India, 60 The Hudson Rev. 359, 362 (2007).

37. See Hazra \& Micevska, Judicial Reforms IN INDiA, supra note 35, at 144-45.

38. Id. at 152.

39. Id.

40. The territories are federally administered entities with distinctive legal features that may relate to the assessment of civil filings. For ease of description we often refer to states and
territories collectively as states. 
Figure 1: Civil Filings and GDP Per Capita, by State, 2005-2010
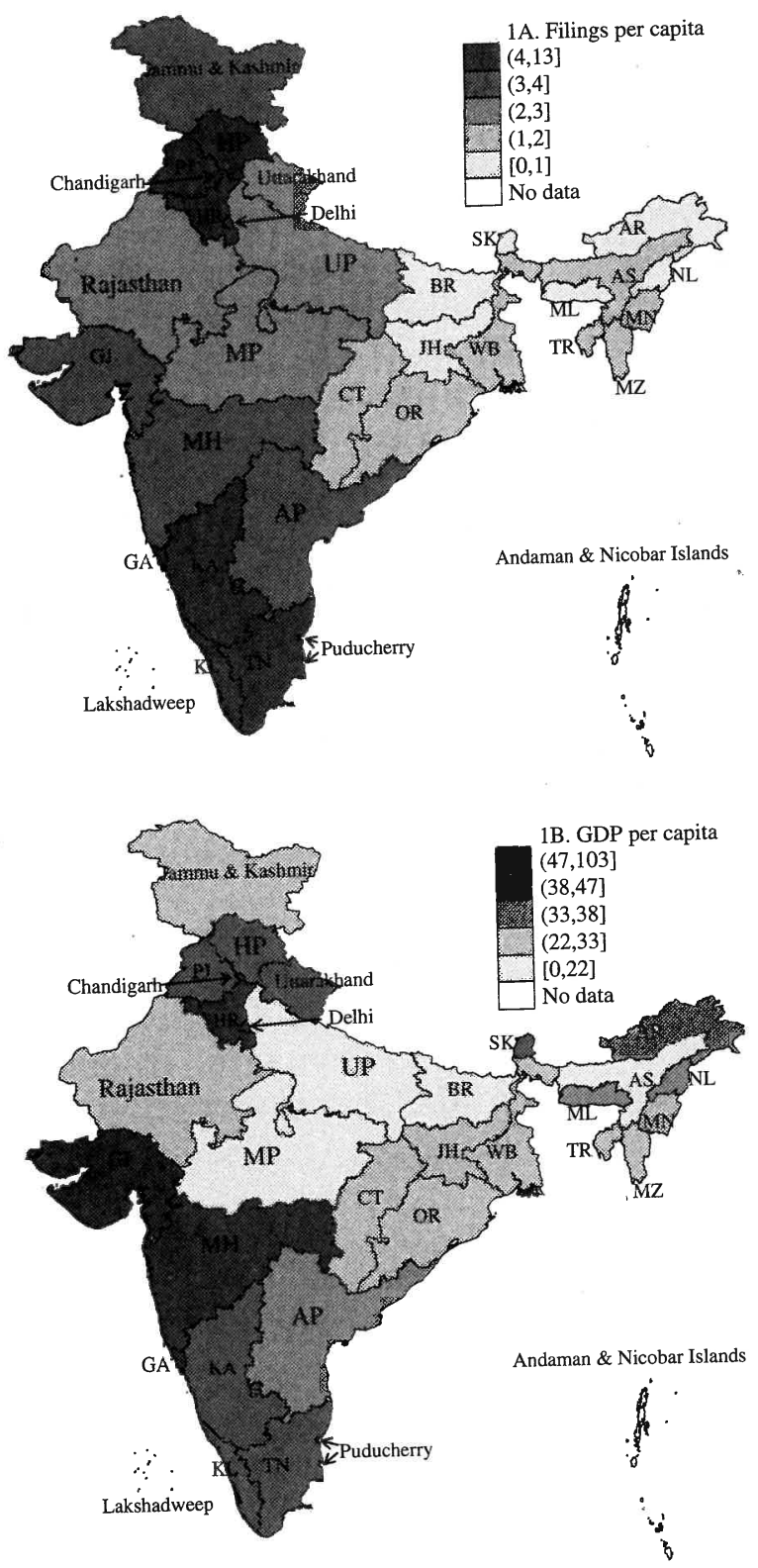

Note: Filings are civil filings per 1,000 persons using lower court filings averaged from 2005 to 2010. GDP is in thousands of rupees per capita averaged for that period. Filing data, GDP data, 2010. GDP is in thousands of a Nagar Haveli, and additional small Puducherry enclaves are not shown. Data not available for Andaman \& Nicobar Islands and Lakshadweep. 
India's unified national court system is headed by the Supreme Court, High Courts of states below it, and lower courts below them. ${ }^{41}$ The High Courts have supervisory power over all courts in their jurisdiction. ${ }^{42}$ The judiciary is regarded as independent of the executive and legislature. Although the President of India has the power to appoint Supreme Court ${ }^{43}$ and High Court justices, ${ }^{44}$ senior Supreme Court justices effectively nominate High Court candidates and the President approves their nominees. ${ }^{45}$ The lower courts include the most important courts of general jurisdiction, which include over 600 district courts, and the other subordinate courts. 46 As of December 31,2010 , there were 13,962 district and subordinate court judges. ${ }^{47}$ Geographical jurisdiction for the twenty-one High Courts coincides with state and territory boundaries, with six High Courts having authority over more than one state or territory. Table 1 shows the allocation of states and territories to the High Courts.

41. INDIA Const. arts. 131-36, 227.

42. Id. arts. $135,138$.

43. Id. art. $124, \S 2$.

44. Id. art. 217.

45. Nick Robinson, Expanding Judiciaries: India and the Rise of the Good Governance Court, 8 WASH. U. Glob. Stud. L. Rev. 1, 25 (2009) ("In the 1990s, the Supreme Court reinterpreted the Constitution to hold that a small collegium of senior justices headed by the Chief Justice would pick its own membership, and the role of the executive became more of a formality."). 46. District Courts of India, INDIAN CourTs, http://indiancourts.nic.in/districtcourt.html (last visited Feb. 10, 2013). In each district, the highest court is headed by a district and sessions judge who may deal with both criminal and civil matters. Below this is a Court of the Civil Judge (Senior Division) for civil matters and the Chief Judicial Magistrate for criminal matters. At the bottom of the court hierarchy is the Court of the Civil Judge (Junior Division) and the court of the Judicial Magistrate for civil and criminal matters, respectively. See id. There are currently 600 districts in India. See List of Districts in India, DEPT. OF LAND RES., dolr.nic.in/hyperlink/ distlistnew.htm (last visited Feb. 10, 2013).

47. See Introduction, Pendency and Disposition, Court News (Supreme Court of India, New Delhi, India), Jan.-Mar. 2011, at 2, 4 [hereinafter INDIA CourT News]. 


\section{Table 1: India High Courts Geographical Jurisdiction}

\begin{tabular}{|c|c|c|}
\hline Name of High Court & States included & Union territories included \\
\hline Andhra Pradesh & Andhra Pradesh & \\
\hline Allahabad & Uttar Pradesh & \\
\hline Bombay & Maharashtra; Goa & $\begin{array}{l}\text { Daman \& Diu, Dadra \& } \\
\text { Nagar Haveli }\end{array}$ \\
\hline Calcutta & West Bengal & Andaman \& Nicobar Islands \\
\hline $\begin{array}{l}\text { Chhatisgarh } \\
\text { Delhi }\end{array}$ & Chhatisgarh & \\
\hline $\begin{array}{l}\text { Delhi } \\
\text { Gujarat }\end{array}$ & & Delhi \\
\hline $\begin{array}{l}\text { Gujarat } \\
\text { Gauhauti }\end{array}$ & Gujarat & \\
\hline Gauhauti & $\begin{array}{l}\text { Assam; Nagaland; Manipur; } \\
\text { Meghalaya; Tripura; Mizoram; } \\
\text { Arunachal Pradesh }\end{array}$ & \\
\hline Himachal Pradesh & Himachal Pradesh & \\
\hline Jammu \& Kashmir & Jammu \& Kashmir & \\
\hline Jharkhand & Jharkhand & \\
\hline Karnataka & Karnataka (formerly Mysore) & \\
\hline Kerala & Kerala & Laksahdweep \\
\hline Madhya Pradesh & Madhya Pradesh & \\
\hline Madras & Tamil Nadu & $\begin{array}{l}\text { Puducherry } \\
\text { (formerly Pondicherry) }\end{array}$ \\
\hline Orissa & Orissa & \\
\hline Patna & Bihar & \\
\hline Punjab \& Haryana & Punjab; Haryana & Chandigarh \\
\hline Rajasthan & Rajasthan & \\
\hline Sikkim & Sikkim & \\
\hline Uttarakhand & $\begin{array}{l}\text { Uttarakhand } \\
\text { (formerly Uttaranchal) }\end{array}$ & \\
\hline
\end{tabular}

Note: The table shows the current allocation of states and territories to High Courts. During the periods covered by data we use, the Himachal Pradesh High Court was established in 1971, Sikkim became a state with its own High Court in 1975, the Gauhauti High Court's jurisdiction was expanded to cover seven states in 1987, and Chhatisgarh, Jharkhand, and Uttarkhand all became states with their own respective High Courts in $2000 .^{48}$

\section{Hypotheses AṄd Data}

India's federal structure allows for testing hypothesized associations between litigation rates and both economic prosperity and other factors. For a within-country study of litigation rates and prosperity, India has the useful but lamentable characteristic of substantial variation in economic development. GDP per capita varies across states by

48. Further information regarding the histories of these High Courts can be found on their respective websites. See History, High Cт. Himachal Pradesh, http://hphighcourt.nic.in/hist. htm (last visited Feb. 13, 2013); Historical Perspective of the Sikkim Judiciary, НigH Ст. SiкKIм, http://www.highcourtofsikkim.nic.in/sj.html (last visited Feb. 13, 2013); History, GaUHAUTI HIGH CT., http://ghconline.nic.in/history_more.html (last visited Feb. 13, 2013); Home, HiGH CT. ChHATtisGarH, http://highcourt.cg.gov.in/default.htm (last visited Feb. 13, 2013); History, JHARKHAND HigH CT., http://jharkhandhighcourt.nic.in/History.html (last visited Feb. 13, 2013); About Us, HigH CT. UTTARAKHAND, http://highcourtofuttarakhand.gov.in/pages/display/154about-us (last visited Feb. 13, 2013).

$$
\text { I }
$$


nearly a factor of ten, ${ }^{49}$ compared, for example, to a variation by a factor of roughly two in the U.S.50 We exploit this variation and similar state-level variations in other attributes, such as education and life expectancy, to formulate and test hypotheses about their influences on litigation rates.

\section{A. Hypotheses}

As previously described, scholars have long noted that economic growth may create more litigation. ${ }^{51}$ More specifically, as economies grow in size and complexity, litigation increases "both to resolve social conflict and more simply as a mechanism of economic interaction." 52 Like many studies, ${ }^{53}$ we therefore hypothesize that litigation rates will be higher in Indian states that are more economically prosperous, based on state-level measures of GDP per capita.

The association between noneconomic well-being and litigation rates is less widely acknowledged. An impoverished, uneducated field worker in poor health faces obstacles other than money to securing rights: lack of education likely reduces knowledge of one's private and public rights; ill-health may disable one from many activities, including litigation; and shorter life expectancies provide less time to sue. In addition to these direct effects on litigation, less education and shorter life expectancies may compromise economic development, and thereby indirectly influence litigation rates through economic measures.

In countries with substantially homogenous literacy and health rates, the influence of noneconomic well-being on within-country litigation rates may be difficult to detect and has not been analyzed. India's states, much more than the Japanese prefectures studied by Ginsburg and Hoetker or the U.S. states studied by Jacobi, vary substantially in noneconomic measures of human well-being, such as life expectancy, education, and literacy. ${ }^{54}$ In analyzing litigation rates, we employed a widely used measure of well-being that includes

49. See infra Table 2.

50. U.S. state GDP calculations are based on the 2009 state population table and the 2008 state GDP table. See Resident Population-July 2009, in State Rankings, U.S. Census Bureau (Dec. 22, 2009), http://www.census.gov/compendia/statab/2012/ranks/rank01.html; Gross Domestic Product by State in Current Dollars, 2008, in State Rankings, U.S. CENSUs BuREAU (June 2, 2009), http://www.census.gov/compendia/statab/2012/ranks/rank28.html. Including the District of Columbia increases the variation to a factor of about five.

51. See, e.g., F. Van Loon \& E. Langerwerk, Socioeconomic Development and the Evolution of Litigation Rates of Civil Courts in Belgium, 1835-1980, 24 LAw \& SoC'y REv. 283, 285 (1990).

52. Jacobi, supra note 21, at 214.

53. See, e.g., Ginsburg \& Hoetker, supra note 23, at 51; Jacobi, supra note 21, at 205.

54. See infra Table 2. 
noneconomic factors-the Human Development Index (HDI). The HDI is a multidimensional measure of well-being that combines measures of life expectancy, educational achievement, and per capita expenditure. $^{55} \mathrm{We}$ speculate that litigation rates are positively associated with higher HDI scores.

India's population density varies substantially across states. ${ }^{56}$ Increased urbanization likely leads to greater business and personal interactions, thereby creating more opportunities for disputes and litigation. Interpersonal and kinship relations in urban settings may be generally weaker, thereby also contributing to higher litigation rates. ${ }^{57}$ Moreover, lawyers tend to be more concentrated in urban areas, thereby reducing the transaction costs of obtaining a lawyer and thus promoting litigation. ${ }^{58}$ Wollschläger's study of litigation rates over time in Bremen noted that the effects of urbanization on litigation need "no comment," 59 and Ginsburg and Hoetker accounted for large urban prefectures in assessing filings. ${ }^{60}$ Drawing similar inferences, we also speculate that states with more urbanization will have higher litigation rates.

Accounting for institutional features of a legal system is also important in assessing litigation rates, as shown in Ginsburg and Hoetker's study of Japan.61 The two most notable institutional features of India's judiciary are perhaps a widespread belief in the existence of substantial corruption ${ }^{62}$ and delays due to a large backlog of cases. India's lower court case backlog was over twenty-six million cases as of 2008.63 We lack information to study the effect of corruption, but have reasonable information about filed, pending, and disposed cases

55. See, e.g., Human Development Index (HDI), United Nations Development ProGRAMME, http://hdr.undp.org/en/statistics/hdi (last visited Feb. 13, 2013). The HDI index measures health (life expectancy), living standards (GDP per capita), and education (literacy and years of schooling). See id.; see also Jeni KLugman et AL., United Nations Development Programme, The HDI 2010: New Controversies, Old Critioues 3 (2011), available at http:/ /hdr.undp.org/en/reports/global/hdr2011/papers/HDRP_2011_01.pdf. In 2010, gross national income replaced GDP as the measure for living standards. KLUGMAN ET AL., supra, at 15.

56. See infra Table 2.

57. Cf. Ginsburg \& Hoetker, supra note 23 , at $44-45$.

58. Cf. id. at $38-39$.

59. Wollschläger, supra note 6 , at 279 ("The specific effects of urbanization . . on litigation need no detailed comments here.").

60. See Ginsburg \& Hoetker, supra note 23, at 49 tbl.3.

61. Id. at 37-42 (accounting for factors such as the expansion of the bar, law reform, and system capacity as measured by the number of judges).

62. See Justice Without Delay, supra note 8.

63. Id. at 9; Kannan Kasturi, Civil Litigation? No, Thanks., India Together (July 12, 2009), $\mathrm{http}: / /$ www.indiatogether.org/2009/jul/gov-civil.htm (noting a total case backlog of thirty million cases). 
to account for the degree of delay across states. In the U.S., where there is dramatically less delay in the judicial system compared to India, evidence exists that a litigant will choose between a bench or jury trial based on the expected difference in adjudication time. ${ }^{64} \mathrm{We}$ expect greater delay to discourage litigation and to be associated with reduced litigation rates.

\section{B. Data}

\section{Data on Litigation Rates}

To assess litigation rates, we use two types of civil filings: one based on filings in the district and subordinate courts (collectively, the lower courts), and a second based on filings in the High Courts. The case filing data are for civil cases filed in each state's lower courts, as reported in the India Supreme Court's Court News, which is published four times per year and contains quarterly data for the years 2005-2010.65 Court News also provided High Court civil filing data comparable to the lower court data. For High Courts not coterminous with a single state, we recalculated total population at the High Court level, using the geographical coverage of the High Courts shown in Table 1 to compute filings per capita. Data on lower court filings are also available for 1977 from a report of the Law Commission of India. ${ }^{66}$ We have not located conveniently available lower court civil case filing data for years before 2005, other than for $1977 .{ }^{67}$

Lower court data have the advantage of including the mass of civil filings and thus likely provide the most thorough measure of litigation activity. High Courts are more removed from the mass of civil filings and their appellate dockets exclude all the cases that never lead to appeals. Parties may forego appealing for reasons that apply in any country, including acceptance of the lower court's ruling as correct or, even if the ruling is believed to be incorrect, an estimate that the chance of success on appeal is too low to warrant the investment. In

64. See Kevin M. Clermont \& Theodore Eisenberg, Trial by Jury or Judge: Transcending Empiricism, 77 CORNELl L. Rev. 1124, 1147-48 (1992) (showing that litigants tend to select shorter trial queue in opting for judge versus jury trial).

65. Much of the filing data are also available at IndiaStat, which requires password or IP access. See IndiaStat, http://www.indiastat.com (last visited Feb. 10, 2013).

66. See Law Comm'n of India, Delay and Arrears in Trial Courts $63-76$ (1978).

67. Prior to 2005, the available data do not provide separate numbers for civil cases instituted in a year. See, e.g., Ministry of Law \& Justice, Gov't of India, State-Wise Number of Civil and Criminal Pendency Cases in District and Sub-Ordinate Courts in India (2004). This report is also available at IndiaStat. See supra note 65. 
the U.S., for example, the vast majority of trial court outcomes are not appealed. ${ }^{68}$

High Court data, however, have some advantages. First, only twenty-one High Courts exist and they presumably have reasonable information about their own case filings. Lower court data used for this study were supplied to the High Courts from hundreds of lower courts, which then supplied them to the Supreme Court. This process provides less assurance of consistent reporting for lower courts.

Second, High Court filings provide a measure of what are likely the most important cases because they are the cases that parties press to appeal and presumably involve higher stakes. A High Court, for example, had original jurisdiction over the case against then-Prime Minister Indira Gandhi69 that led to the declaration of the State of Emergency from June 26, 1975 to March 23, 1977, during which opposing political party leaders were arrested, press censorship was used, and elections were postponed. ${ }^{70}$

Third, High Courts in India have much wider original jurisdiction than in many other countries, including jurisdiction over revenue matters ${ }^{71}$ and jurisdiction to issue writs of habeas corpus, mandamus, prohibition, quo warranto, and certiorari. ${ }^{72}$. Original jurisdiction High Court cases can number in the tens of thousands in a year ${ }^{73}$ and comprised $52 \%$ of cases filed in the state of Orissa in $2009 .{ }^{.74}$ Thus, many High Court cases did not originate in the lower courts.

68. See, e.g., Theodore Eisenberg, Appeal Rates and Outcomes in Tried and Nontried Cases: Further Exploration of Anti-Plaintiff Appellate Outcomes, 1 J. EMPIRICAL LeGAL STUd. 659, 663 (2004).

69. State of Uttar Pradesh v. Raj Narain, A.I.R. 1975 S.C. 865 (Allahabad High Court) (India). The Supreme Court of India stayed the ruling and later overturned the conviction of Gandhi.

70. Cf. S. P. Sathe, Judicial Activism in India 101 (2002). The immediate impetus of the emergency was a High Court ruling that Indira Gandhi had committed corrupt practices during her election campaign and was therefore disqualified from holding office for six years.

71. See InDia Const. art. 225. Six High Courts have original jurisdiction in civil cases involving sufficient amounts, while other High Courts have more specialized original jurisdiction. See Arnub Kumar Hazra \& Bibek Debroy, Introduction to Judicial Reforms IN INDIA, supra note 35 , at $15,17-18$.

72. See India Const. art. 226, § 1.

73. See Dep't of Econ. \& Stat., Gov't of Tamil Nadu, Statistical Hand Book 2010, at 175 tbl.32.2 (2010); Directorate of Econ. \& Stat., Gov't of Andhra Pradesh, StatistiCal Abstract Andhra Pradesh 2001, at 343 tbl.23.1 (2002).

74. This is based on analysis of the Supreme Court's Court News publications that contain data for 2009. See India Court News, supra note 47, Jan.-Mar. 2010, at 8-10; id., Oct.-Dec. 2009, at 7-9; id., July-Sept. 2009, at 7-9; id., Apr.-June 2009, at 7-9. In 2009, 22\% of the total cases filed in India were filed in the High Court. We arrive at this ratio by dividing the number of High Court cases decided in a year by the total number of High Court and subordinate court cases decided in the same year. 
[Vol. 62:247

Fourth, High Court data provide a check on the lower court data. A high association between lower court and High Court filings ought to exist across the states. An appeal cannot be filed without a lower court ruling, therefore, lower court activity imposes a fundamental constraint on High Court activity that should promote an association. Moreover, concerns about India's civil justice system have generated the view that High Courts are reluctant to deny admission of appeals. ${ }^{75}$

Separate recent lower court civil case filing data are available for the twenty-eight states and for the three largest union territories: Delhi, ${ }^{76}$ Chandigarh, ${ }^{77}$ and Puducherry. ${ }^{78}$ India has four other union territories, all substantially smaller, with an aggregate population of about one million people, ${ }^{79}$ less than $0.1 \%$ of India's roughly 1.2 billion people. ${ }^{80}$ These small union territories are not included in our lower court analysis.

Our analysis of lower court and High Court filing data covering 2005-2010, discussed later, established that High Court data are a reasonable proxy to assess the relation between economic prosperity and

75. See Pratap Bhanu Mehta, India's Judiciary: The Promise of Uncertainty, in Public Institutions in India: Performance and Design 158, 181 (Devesh Kapur \& Pratap Bhan Mehta eds., 2005) [hereinafter Public Institutions IN INDiA].

76. Delhi is India's National Capital Territory. See IndIA Const. art. 239AA, §§ 2-4. It contains, by at least one measure, the largest city population in India, see India, in World Factbook, CENT. INTELLIGENCE AGENCY, https://www.cia.gov/library/publications/the-world-factbook/geos /in.html (last updated Feb. 5, 2013), and is one of the ten largest metropolitan areas in the world, see Largest Cities of the World (By Metro Population), Worldatlas, http://www.worldatlas. com/citypops.htm (last visited Feb. 10, 2013). Its administration includes its own legislature, High Court, and executive council of ministers headed by a chief minister. INDIA Const. art. 239AA, $\$ \S 2-4$.

77. Chandigarh is a union territory and planned city that arose out of the partition of British India into Pakistan and India. In the partition, the former province of Punjab was split between Pakistan and India. The capital of the former province, Lahore, became part of Pakistan. Thus, the newly formed entity on the Indian side needed a new capital. In addition, in 1966, the new state of Haryana was created out of the eastern portion of India's Punjab. The surviving portion of Punjab had a Sikh and Punjabi language majority; Haryana had a Hindu and Hindi language majority. Chandigarh serves as the capital of two states, Punjab and Haryana, see About Chandigarh, ChANDIGARH ADMIN., http://chandigarh.gov.in/knowchd_general.htm (last visited Feb. 10, 2013), and is, by Indian standards, of modest size with a population of about one million. See Office of Registrar Gen. \& Census Comm'r, Gov't of India, Census of India 2011: Provisional Population Totals 47 (2011) [hereinafter India Census 2011], available at http://www.censusindia.gov.in/2011-prov-results/data_files/india/Final_PPT_2011_chapter3.pdf.

78. Puducherry is a union territory that was a French colony and consists of four districts that are not contiguous. Like Delhi, Puducherry has its own elected legislative assembly and executive council of ministers. India Const. art. 239A, § 1. Puducherry's population is larger than Chandigarh's, but is still less than 1.5 million people. India Census 2011, supra note 77.

79. The four smaller union territories are Andaman and Nicobar Islands, Dadra and Nagar Havel, Daman and Diu, and Lakshadweep.

80. India Census 2011, supra note 77. 
civil filings. We therefore extended our analysis to years for which High Court filing data were available prior to 2005. High Court civil filing data for the years 1964-1983 (other than 1966) are contained in the Jaswant Singh Commission Report, ${ }^{81}$ a government study undertaken to assess the necessity of adding High Courts or benches (locations) within High Courts. To compute High Court per capita civil filings and GDP per capita for the earlier time period, we used the 1961 Census data for the years 1964-1965; for the years 1967-1976, we used the 1971 Census data; and for the years 1977-1981, we used the 1981 Census data.

\section{Data on Economic Well-Being}

As a measure of economic well-being for the time period 2005-2010, we used state-level data for each year provided by the Government of India through its Ministry of Statistics and Programme Information. The data are reported as net state domestic product in rupees at current prices, ${ }^{82}$ which is GDP minus depreciation on capital goods. Some suggest that net domestic product is a better measure of growth than GDP, ${ }^{83}$ and data for it are the best conveniently available data on economic growth that we have for the state level. We take the liberty of referring to it as GDP because that term is so commonly associated with measures of growth. ${ }^{84}$ For High Courts not coterminous with single states, we recalculated total GDP at the High Court level using the geographical coverage of the High Courts shown in Table 1. As a measure of economic well-being for the High Court data for the period 1964-1983, we again used GDP at the state level.

81. Dep't of Justice, Gov't of India, Jaswant Singh Comm'n, Report on the General Question of Having Benches of the High Courts at Places Away from Their Principal Seats and Broad Principles and Criteria to Be Followed in Regard Thereto 64-66 (1985).

82. See Per Capita Net Income, Press Info. Bureau, Gov't of India (Aug. 4, 2011), http:// pib.nic.in/newsite/AdvSearch.aspx (search for "per capita income" (without quotation marks), from Aug. 1, 2011 to Aug. 31, 2011, and select Ministry of Statistics and Programme Implementation from the drop-down menu; then follow "search" hyperlink; then follow "per capita income" hyperlink) [hereinafter India Per Capita Net Income]. These net domestic product data come from the Indian government's Central Statistics Office.

83. E.g., Roland Spant, Why Net Domestic Product Should Replace Gross Domestic Product as a Measure of Economic Growth, InT'L Productivity Monitor, Fall 2003, at 39. This source also compares net domestic product and GDP performance for member countries of the Organization for Economic Co-Operation for Development, showing generally little difference. Id. at 42 tbl.1.

84. For India, these data have sometimes erroneously been referred to as GDP data. See List of Indian States by GDP, WIKIPEDIA, http://en.wikipedia.org/wiki/List_of_Indian_states_by_ GDP (last visited Feb. 10, 2013). 
[Vol. 62:247

\section{Data on Noneconomic Well-Being}

As noted above, we used the HDI as a measure of noneconomic well-being. We have state-level data for fewer geographical units for the HDI than for litigation rates and GDP. Therefore, our analyses that include the HDI encompass fewer states but still include a substantial majority of the states. The state-level HDI data used here are for 2007-2008, come from the India Human Development Report published in 2011, and are reported (as of this writing) to be the most recently available state-level HDI measure. ${ }^{85}$ We also explore the association between litigation rates and literacy rates. We used literacy rates from the 2011 Census.

\section{Data on Urbanization}

We used population density as a measure of urbanization. Density is computed by dividing a state's population in the 2011 Census by its square kilometers to yield the number of inhabitants per square kilometer. The decennial census data from the Ministry of Statistics and Programme Implementation provided population density information. ${ }^{86}$

\section{Data on Court Backlogs}

Our analysis of the relation between litigation rates and court backlogs is limited to 2005-2010 and to the lower courts, where most cases begin. Data on filed, pending, and disposed cases come from Court News. As a measure of the backlog, for each state and for each year, we divided the number of pending civil cases by the number of disposed civil cases. This yielded the number of years needed to clear the civil docket, as shown in Table 2. The number of years required to clear the civil docket should not be confused with the average number of years required for a case to be heard and decided by a court. Many cases are settled or withdrawn before they are heard, but these cases are still counted as disposals. This measure of backlog also effectively assumes a first-in, first-out treatment of cases, with subsequently filed cases being delayed until previously filed cases are processed. Be-

85. Inst. of Applied Manpower Research, Planning Comm'n, Gov't of India, India Human Development Report 2011, at 24 tbl.2.4 (2011) [hereinafter India Human DevelopMENT REPORT 2011].

86. India Statistics, Area and Population by States, Ministry of Statistics \& Programme IMPLEMENTATION, http://mospi.nic.in/Mospi_New/site/India_Statistics.aspx?status=1\&menu_ id=14 (follow "India an Overview" hyperlink; then follow "Chapter 2 AREA AND POPULATION" hyperlink; then follow "TABLE 2.1 - AREA AND POPULATION BY STATES" hyperlink) (last visited Feb. 10, 2013). 
cause some classes of litigation enjoy priority, ${ }^{87}$ and other factors are undoubtedly at work, the measure is not intended as a precise indicator of how long cases will remain on the docket or how many years it would take for a case to be decided by a court. We merely used it as a proxy for comparing delay across states. Note that the measure effectively accounts for other factors that may influence case processing time, such as the number of judges in a state's court system and the economic resources devoted to the court system. The effect of more judges or resources should translate into greater capacity to process cases and therefore reduce the time needed to clear the cases from the system.

\section{Data Limitations}

Two primary challenges exist in using data available on the Indian court system. The first is the potential for lack of uniformity in recordkeeping over time and across states. In data available for 1977, for example, regular hearing and miscellaneous filings are disaggregated. ${ }^{88}$ The data for 2005-2010 seem to only include regular hearing filings, but the inclusion of miscellaneous filings by any of the state courts would create inconsistencies in the data. ${ }^{89}$ A state-specific concern is that Tamil Nadu's filing rate is far above that of any other state, as shown in Table 2 below, and exceeded only by the much more densely populated and far more prosperous union territory of Puducherry. It would not be surprising if Tamil Nadu courts account for cases differently than other states. ${ }^{90}$

The second potential challenge is the possibility of error in recordkeeping. Most data available for different state lower and High

87. LaW Comm'N of INDIA, supra note 66, at 37 (noting that matrimonial, eviction, Motor Accident Claims Tribunal, and India Succession Act cases should be given priority).

88. Miscellaneous filings are interlocutory appeals, requests for stay, and requests for interim orders, which result from preexisting regular hearing filings.

89. We used the comparable filings data available for 1977. See LAw Comm'N OF India, supra note 66 .

90. Some possible causes of this outlier do not fully account for the variation. The volume of not large enough to materially affect results. See Lok Sabha Unstarred ly Courts, MiNISTRY of LAw \& Justice, Gov'T OF INDIA (answered on Question No. 6743 Family Court, 2 /Annexture//sq15/4/au6743.htm (showing less than 250,000 Nor does the number of cases disposed of by Lok Adalat new family court cases per year). Nor do the observed patterns. See Cases Disposed (people's court) methods seem large enough to affors off [sic] by Lok Adalat Methods, NAT'L Consum; then follow "Statistics" hyperlink; then follow nic.in (follow "General Information" hyperlink, the fated Feb. 8, 2013); Lok Sabha Unstarred "Lok Adalat" hyperlink at bottom of page) (last updated Feb. 8, 201'T OF INDIA (answered on Question No. 3571 Lok Adalats, MiNISTRY OF LAW \& JUSTCE, Gov For a discussion of Lok Aug. 20, 2004), http://164.100.47.132/Annexture/lsq

Adalats, see Galanter \& Krishnan, supra note 11. 
Courts seem to vary reasonably from year-to-year. However, there are occasionally unexplained spikes or dips in litigation filing; we note some of these in reporting our results.91 This may represent actual volatility in litigation filing or may simply be a recordkeeping error. Overall, the data on the Indian courts is reasonably uniform. Accordingly, although these potential challenges should be kept in mind, they do not seem to significantly undercut our conclusions.

Our analysis has limitations other than the consistency and accuracy of the data. The lack of data at the district level is a concern. Although many state-level empirical and policy studies in India and the U.S. exist, state-level comparisons cannot account for within-state heterogeneity. State-level studies effectively treat New. York City the same as upstate New York and Mumbai the same as rural Maharashtra. India's substantial differences between urban and rural areas, even within states, suggest that state-level studies necessarily oversimplify. The sheer size of some Indian states exacerbates this concern. Uttar Pradesh's population of approximately 200 million people, standing alone, would make it the fifth most populous country in the world. ${ }^{92}$ Representing its economy and courts by using statistics for the entire state is not fully satisfactory.

The available data also do not include useful information about subcategories of civil cases. Some hypothesized relations, such as the effect of the HDI on filings, likely influence different types of cases to different degrees. Finally, data on civil filing rates are not available for different income and social groups. For example, although India's litigation rate overall may be low compared to a country like the U.S., ${ }^{93}$ the filing rate of Indians making over $\$ 30,000$ annually may be as high or higher than Americans in a comparable income bracket. To more accurately compare whether a society is more litigious than another, one should contrast the filing rates of like social groups, whether measured by GDP per capita, HDI, or other relevant factors. ${ }^{94}$

91. See infra note 98; see also infra Figures 9-12 and accompanying text.

92. INDIA CENSUs 2011, supra note 77, at 46.

93. Jacobi shows a mean filing of 168,764 and a mean population of $5,034,887$ for U.S. states. See Jacobi, supra note 21, at 208. This corresponds to filings of 33.5 per 1,000 persons, far higher than the per capita filing rate for any Indian state shown in Table 2. See infra Table 2.

94. Ideally, this study would benefit from a more precise base measure of possible litigation events than proxies such as population or economic conditions. For example, a study of tort litigation in Thailand used motor vehicle registrations as a proxy for possible automobile accident litigation. See Davm M. Engel \& Jaruwan S. Engel, Tort, Custom, and Karma: Globalization and Legal Consciousness in Thailand 105-06 (2010). 
Table 2 provides summary statistics for our key variables for the thirty-one geographical units we analyzed using lower court filings. ${ }^{95}$ The state abbreviations in Table 2's second column are the same as those used in the Figures. To compute 2005 filings per capita, we divided the annual court filings by the state's 2001 population, which is reported in the 2001 Indian Census ${ }^{96}$ and contains the census information closest in time to 2005 . For the 2006-2010 filings per capita, we divided the annual court filings by the state's 2011 population, as reported in the 2011 Indian Census, ${ }^{97}$ which contains the census information closest in time for 2006-2010. The states' civil filings shown in Table 2 are average filings from 2005 to 2010. The GDP per capita and case backlog data in the table are similarly averaged. The filing and GDP data are shown graphically in Figure 1 above. GDP amounts are in rupees and, as of this writing, the exchange rate for rupees is approximately fifty per U.S. dollar. As previously stated, the backlog data show the years needed to clear a state's civil case back$\log$ based on the number of civil cases pending and disposed in a year. ${ }^{98}$

95. We aggregated the case filing data across the relevant Court News issues (four per year) for each calendar year to compute each state's case filings for the years studied. See INDIA Court News, supra note 47, Jan.-Mar. 2011, at 7; id., Oct.-Dec. 2010, at 7; id., July-Sept. 2010, at 7; id., Apr.-June 2010, at 7; id., Jan.-Mar. 2010, at 10; id., Oct.-Dec. 2009, at 10; id., July-Sept. 2009, at 9; id., Apr.-June 2009, at 9; id., Jan.-Mar. 2009, at 9; id., Oct.-Dec. 2008, at 9; id., July-Sept. 2008, at 9; id., Apr.-June 2008, at 10; id., Jan.-Mar. 2008, at 10; id., Oct.-Dec. 2007, at 9; id., July-Sept. 2007, at 10; id., Apr.-June 2007, at 8; id. Jan.-Mar. 2007, at 8; id., Oct.-Dec. 2006, at 8; id., July-Sept. 2006, at 8; id., Apr.-June 2006, at 10; id., Jan.-Mar. 2006, at 9.

96. Office of Registrar Gen. \& Census Comm'r, Gov't of India, Census of India 2001: Provisional Population Totals, Chapter 3, at 5-6 (2001) [hereinafter India Census 2001], available at http://censusindia.gov.in/Data_Products/Library/Provisional_Population_Total_link/PDF_Links/chapter3.pdf.

97. InDia Census 2011, supra note 77, at 46.

98. The backlog average shown for Mizoram in Table 2 is questionable because the 2005 data show only twenty-three cases disposed and 834 cases pending, leading to a "years to clear" back$\log$ of 36.3 years for that year. Excluding 2005 leads to a "years to clear" backlog of 1.7 years. See India Court News, supra note 47, Jan.-Mar. 2006, at 9. 


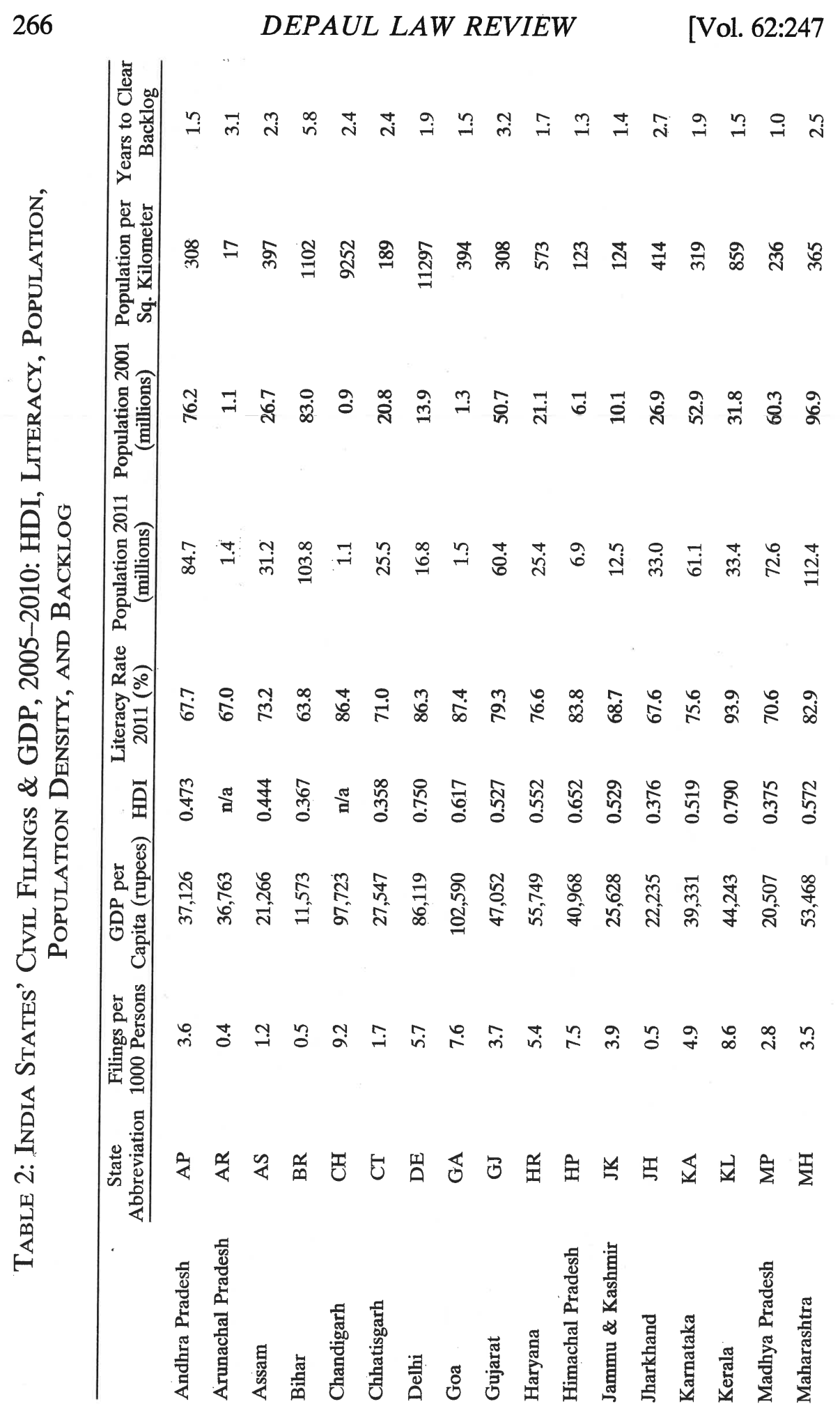


2013] LITIGATION AS A MEASURE OF WELL-BEING 267

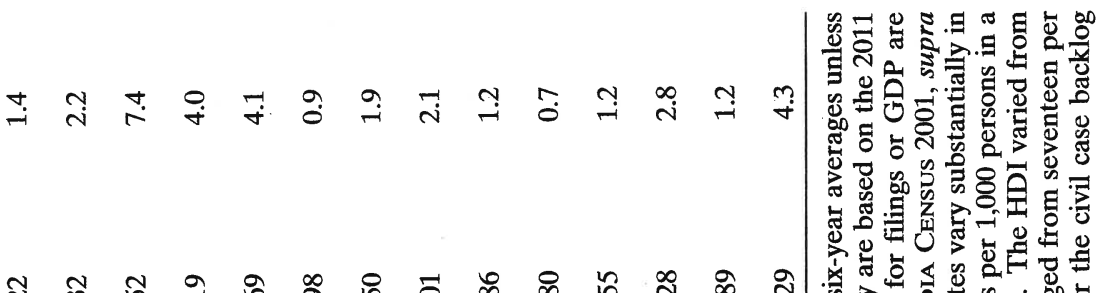

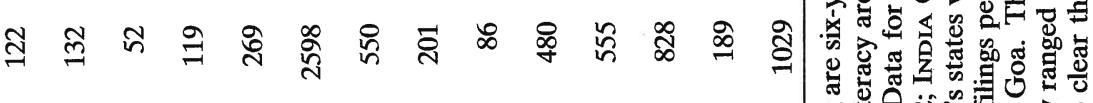

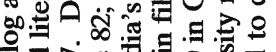

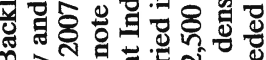

$$
\begin{aligned}
& \text {. }
\end{aligned}
$$

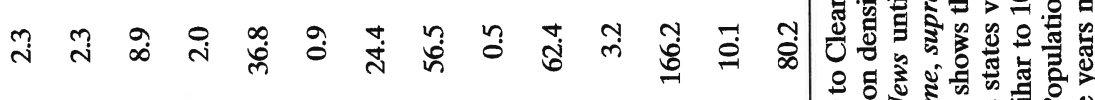

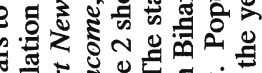

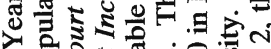

$$
\begin{aligned}
& \text { o }
\end{aligned}
$$

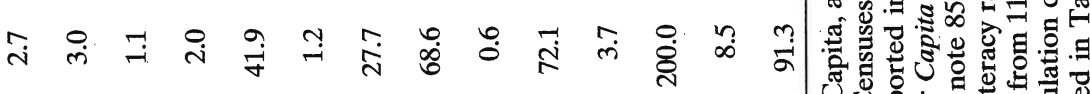

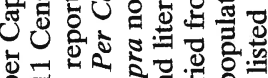

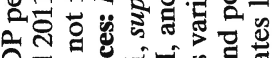

$$
\begin{aligned}
& \text { Oे क्षे }
\end{aligned}
$$

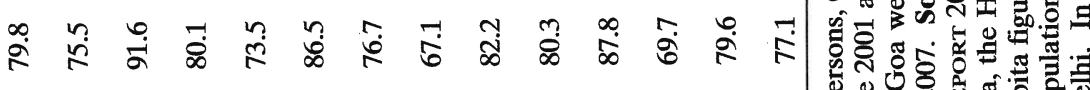

$$
\begin{aligned}
& \text { 엄 }
\end{aligned}
$$

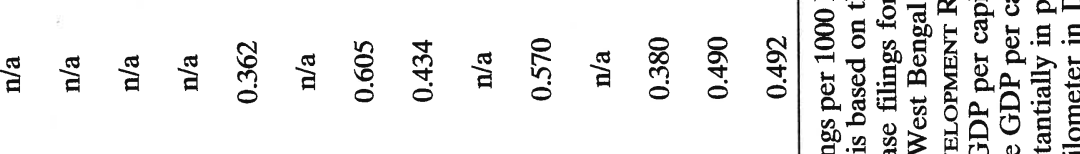

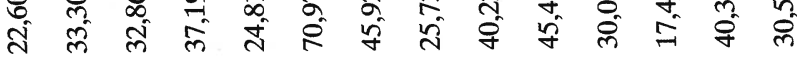

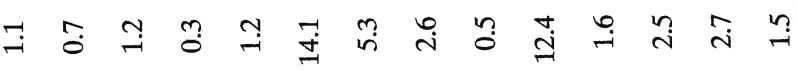

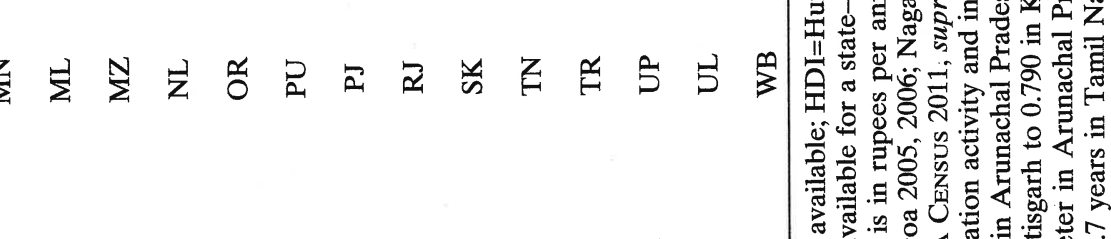

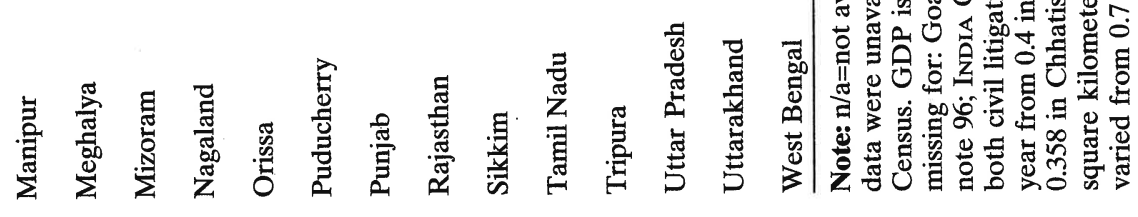




\section{Results}

We first report bivariate results describing the relation between litigation rates and explanatory factors. We then report multivariate linear regression models ${ }^{99}$ that assess the combined influence of the factors on litigation rates.

\section{A. Bivariate Results}

\section{Litigation Rates in Lower Courts: Economic Prosperity and Urbanization}

Figure 2 shows the relation, for each Indian state or major territory, between civil case filings per capita on the y-axis, and GDP per capita on the x-axis. Each of the six subfigures shows the relation for one year, beginning with 2005 in the upper left subfigure, and ending with 2010 in the lower right subfigure. The data points in the subfigures are labeled from left to right, with state abbreviations to show which Indian state has the indicated civil filings and GDP. For example, the state of Bihar (BR) had the lowest GDP per capita in each year and also had relatively low civil case filings per capita in each year.

Figure 2 shows that the relation between civil filings and GDP per capita was reasonably stable over the six-year period-higher filing rates were associated with higher GDP per capita. The figure also shows that the territories of Delhi (DE), Chandigarh $(\mathrm{CH})$, and Puducherry (PU) consistently had relatively high civil filings, accompanied by relatively high GDP. These territories are also distinctive in their population densities (our measure of urbanization), which are by far the highest in India. ${ }^{100}$ Some low-population states, Arunachal Pradesh (AR), Meghalya (ML), Mizoram (MZ), Nagaland (NL), and Sikkim (SK), showed the greatest departures from the pattern of increased civil filings being associated with increased GDP per capita.

Figure 3 shows the average civil filings per capita and GDP per capita for the six years for which we have data, but now also incorporates population density information from Table 2 . The density information helps illuminate the distinctive features of both the territories and the low-population states that emerge in Figure 2. Delhi, Chandigarh, and Puducherry have by far the three highest population densities, as well as high GDP per capita and case filing rates. Thus, these large

99. Multivariate regression is a statistical technique that quantifies the influence that each of several predictor variables has on the outcome variable being studied. See ANDREw Gelman \& Jennifer Hill, Data Analysis Using Regression and Multilevel/Hierarchical ModELS 31 (3d prtg. 2007).

100. See supra Table 2. 
Figure 2: India Civil Filings per Capita \& GDP per Capita, by State, Trial Level, 2005-2010

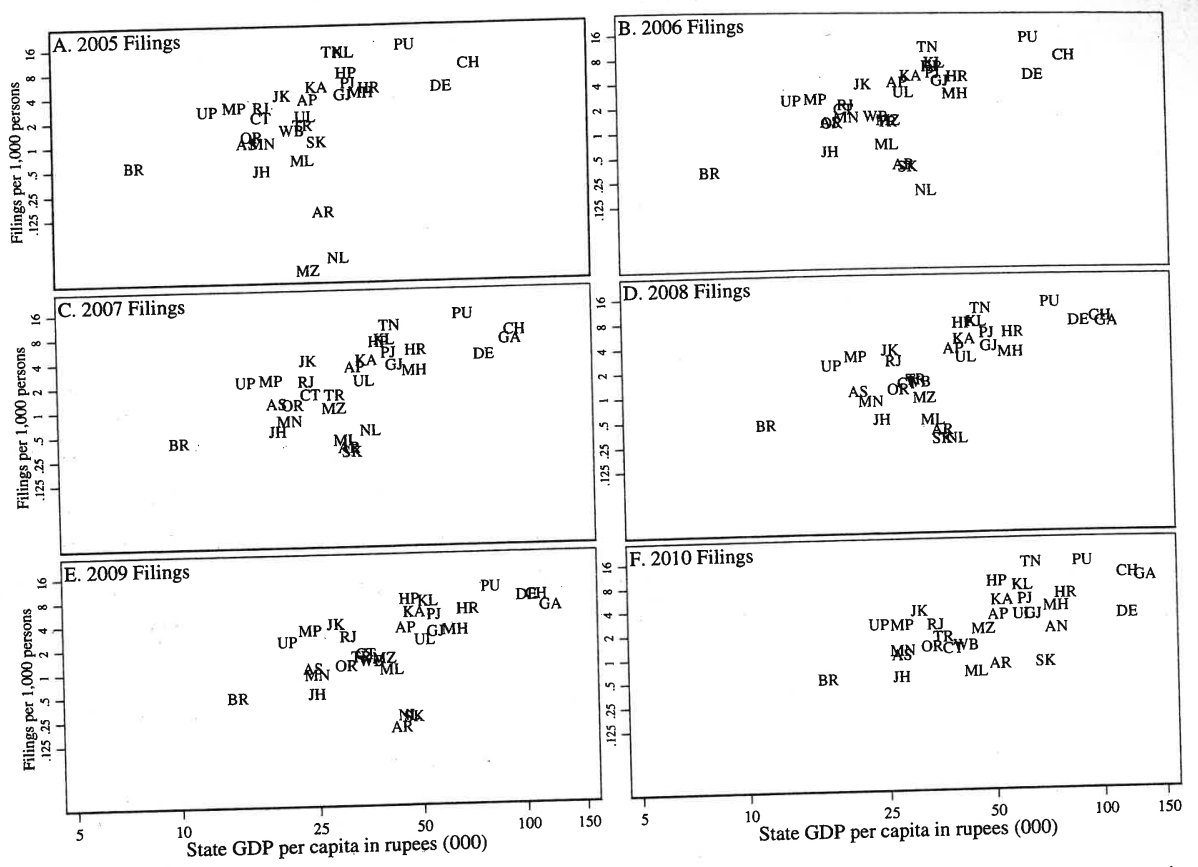

Note. GDP data are based on fiscal years beginning April 1 and ending March 31. State abbreviations are in Table 2. The $\mathrm{x}$ - and $\mathrm{y}$-axis scales are in logs. Sources: Per Capita Net Income, supra note 82; INDIA CENSUs 2001, supra note 96; InDIA CENSUs 2011, supra note 77; INDIA HuMAN DEVELOPMENT REPORT 2011, supra note 85.

union territories are distinctive as legal entities, but also have high population densities that may be associated with high civil litigation rates. The low-population states had low population densities, low case filing rates, and non-distinctive GDP per capita levels. The straight line in Figure 3 shows the predicted values from a regression of the relation between filings and GDP. It confirms the positive association between the two variables. The correlation between filings and GDP is strong, with a correlation coefficient of 0.59 (using log transformations), which is significant at $\mathrm{p}=0.0004 .^{101}$ If one excludes

101. The significance level reported in the text can be viewed as exploring the hypothesis that there is no linear association between filings per capita and GDP per capita. By convention, the hypothesis being tested is called the null hypothesis. See George W. SNedecor \& William G. Cochran, Statistical Methods 64 (8th ed. 1989). The reported significance level, which is also often referred to as a p-value, represents the probability of rejecting the null hypothesis In this case, an incorrect rejection of the null hypothesis would lead to the when it is in fact true. In this caper a linear association between filings per capita mistaken conclusion that there is a linear association between association between the two rates capita. The p-value measures the likelihood that the observed association betwerences. See id. at 
the small, outlier states (ML, SK, AR, and NL), the correlation coefficient is 0.76 , significant at $\mathrm{p}<0.0001$.

Figure 3: India Civil Filings per Capita and GDP Per

Capita, By State, Trial LeVel, 2005-2010, Showing

Population Density

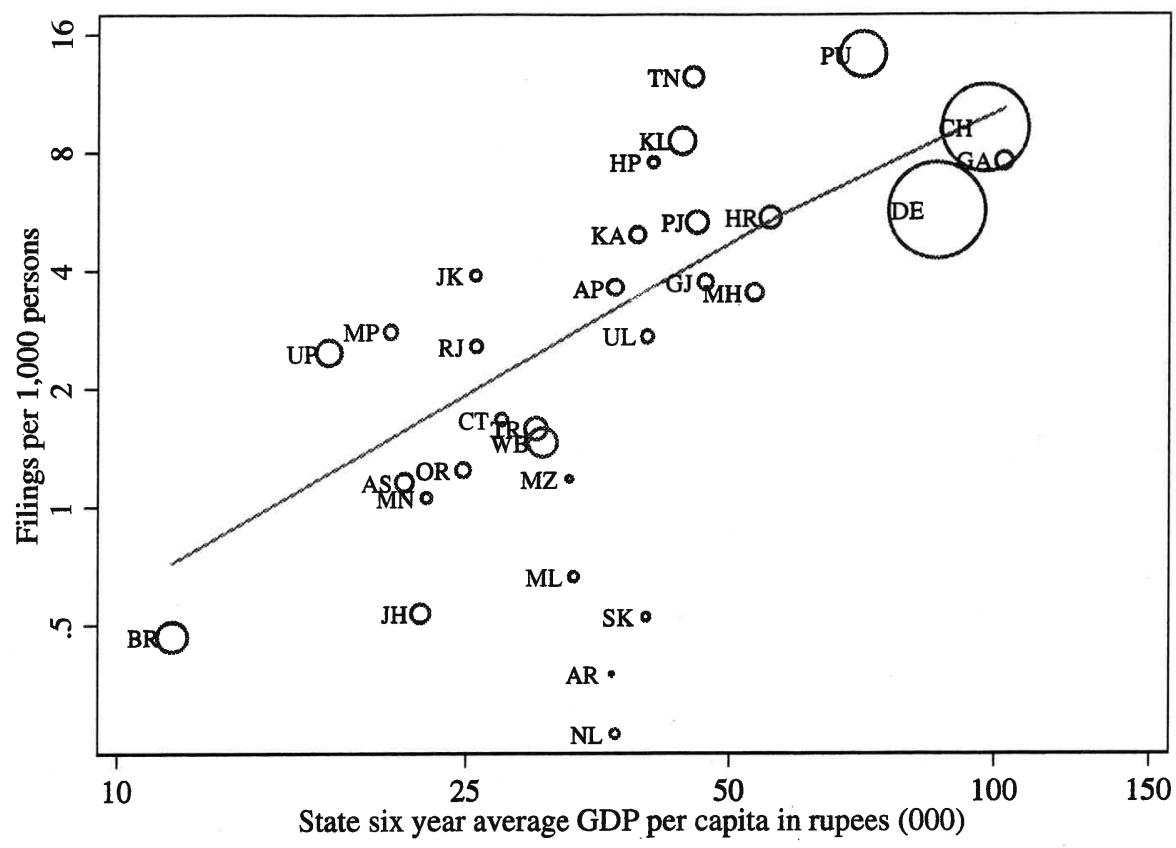

Note: The circles show the data points and the circle sizes are proportional to the states' population densities. State abbreviations are in Table 2 and appear to the left of the circles representing the state's data. The $\mathrm{x}$ - and y-axis scales are in logs. Sources: Per Capita Net Income, supra note 82; INDIA CENSUs 2001, supra note 96; INDIA CENSUs 2011, supra note 77; INDIA HuMAN DEVELOPMENT REPORT 2011, supra note 85.

Figure 4 shifts the analysis from the 2005-2010 time period and shows the relation between 1977 lower court filings data and GDP per capita. The correlation between filings and GDP is similar to that in

64-66. If the $\mathrm{p}$-value is 0.05 , for example, there is a $5 \%$ probability that the observed or larger differences could occur by chance if in fact the null hypothesis were true. By arbitrary convention, p-values at or below the 0.05 level are described as statistically significant. See THE Evolving Role of Statistical Assessments as Evidence in the Courts, 196-97 (Stephen E. Fienberg ed., 1989). The small p-value reported in text indicates that, for these data, one is extremely unlikely to reject the null hypothesis by chance. That is, it is extremely unlikely that there is no association between filings per capita and GDP per capita across India's states. The correlation coefficient can range from -1 to +1 and is a measure of the strength of linear association between two continuous variables. Raymond H. Myers, Classical and Modern ReGRESSION WITH APPLICATIONS 40-41 (1986). 
Figures 2 and 3 , and again large and statistically significant (0.64; $\mathrm{p}=0.001$ ).

Figure 4: India Civil Filings Per Capita AND GDP Per Capita, by State, Trial Level, 1977

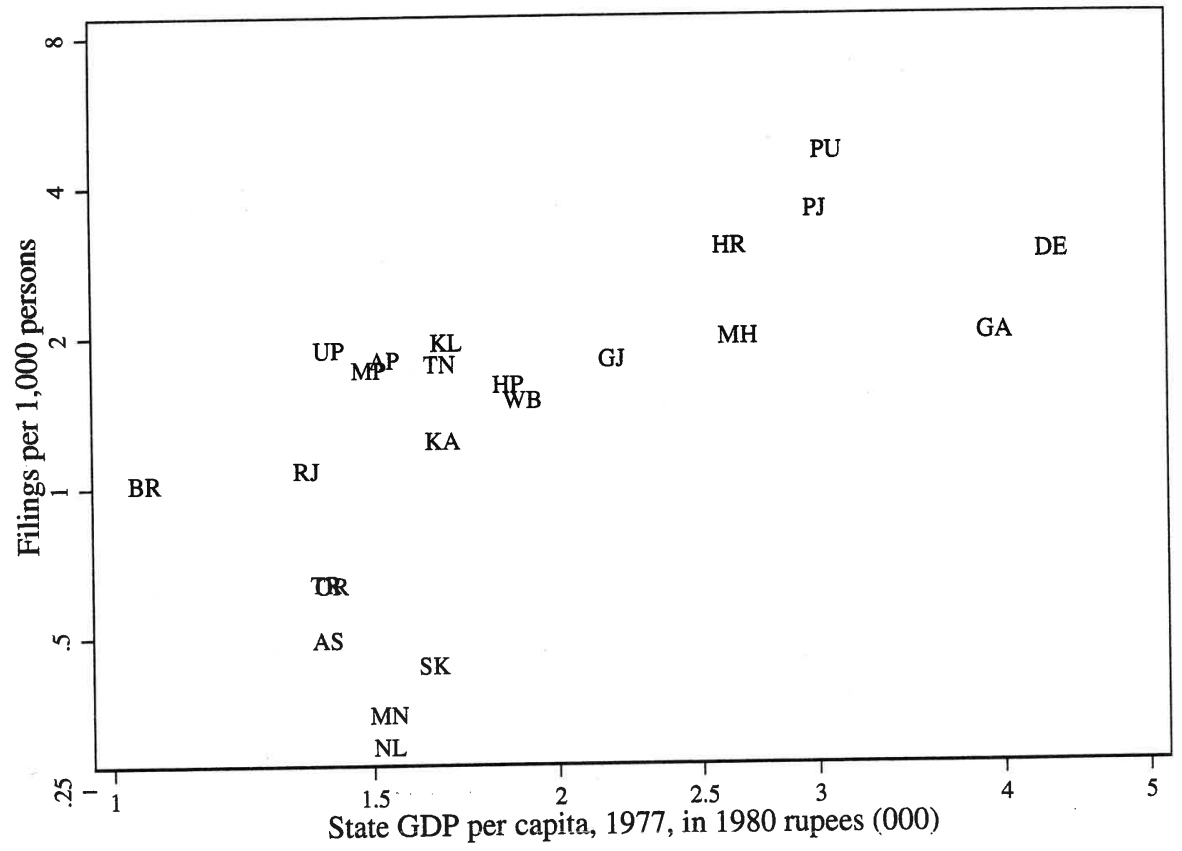

Note: State abbreviations are in Table 2. The $\mathrm{x}$ - and y-axis scales are in logs. Sources: LAw Comm'N OF INDIA, supra note 66; 1981 Census, Directorates of Economics \& Statistics of respective state governments.

We thus have evidence that the strong filings-GDP association at the lower court level dates back over thirty years and of a filings-urbanization association for recent years. ${ }^{102}$ This information allows for assessing within-state variation over time.

\section{Litigation Rates in Lower Courts and Noneconomic Well-Being}

As noted above, GDP measures capture only one aspect of a population's well-being, and India has large internal differences in other important measures of human well-being that may affect litigation rates. Figure 5 compares two other measures, HDI and literacy rates, with civil case filings. We used case filings in the year closest to these

102. GDP per capita and population density are also significantly positively correlated (correlation coefficient $=0.34$ ), but less strongly than is civil filings with each of GDP per capita and population density. 
[Vol. 62:247

available measures: 2007 for the HDI data and 2010 for the 2011 Census-based literacy rates. As in the case of GDP, a strong, statistically significant correlation also exists between both HDI and filings and between literacy rates and filings. ${ }^{103}$ For the twenty-one states for which we have civil filings and HDI data, the correlation coefficient (after log transformations) is $0.80(\mathrm{p}<0.0001)$. For those twenty-one states, the correlation between HDI and civil filings is larger than the correlation between GDP and civil filings $(0.743 ; p=0.0001)$. For those same twenty-one states, the correlation coefficient (after log transformation of filings only) for literacy rates is $0.70(p=0.0005) .{ }^{104}$ The patterns in the figure suggest a stronger association between HDI and filings than between literacy rates and filings. HDI's stronger association than GDP with filings will be explored further in the regression models below.

\section{Litigation Rates in High Courts and Prosperity}

As noted above, the High Court filings-GDP relation provides important potential confirmatory and supplementary information to the lower court filings-GDP correlation. We have analyzed the relation for each of the years 2005-2010 and summarize it in Figure 6 using the averages for the six-year period.

Figure 6 confirms a strong association between filings and per capita GDP. For each year and for the six-year averages, a strong and statistically significant filings-GDP association exists, though the strength of the relation depends on excluding Sikkim. The Figure also suggests that the Sikkim High Court does not fit the overall pattern. That court, with jurisdiction limited to the state of Sikkim has, as shown in Table 2, a small population and services the fewest people-less than one million-of any High Court, by a substantial margin. The strength of association between High Court filings and GDP is similar to the strengths of association between lower court filings and GDP, reported above, though direct comparison is limited due to different numbers of observations and different outliers. If one includes Sikkim, the correlation coefficient for High Court filings and GDP is 0.50 , which is statistically significant at $\mathrm{p}=0.0032$; the correlation coefficient increases to 0.65 , significant at $\mathrm{p}=0.0001$ if one excludes Sikkim.

More importantly, Figure 6, in conjunction with the lower court data, suggests that using High Court data to assess the filings-GDP relation yields results similar to those using the lower court data in

103. See supra Table 2.

104. Direct comparison of the correlations is of limited value because of the different scales and nature of the non-filing variables. 
Figure 5: Relation Between Civil Filings \& Well-Being
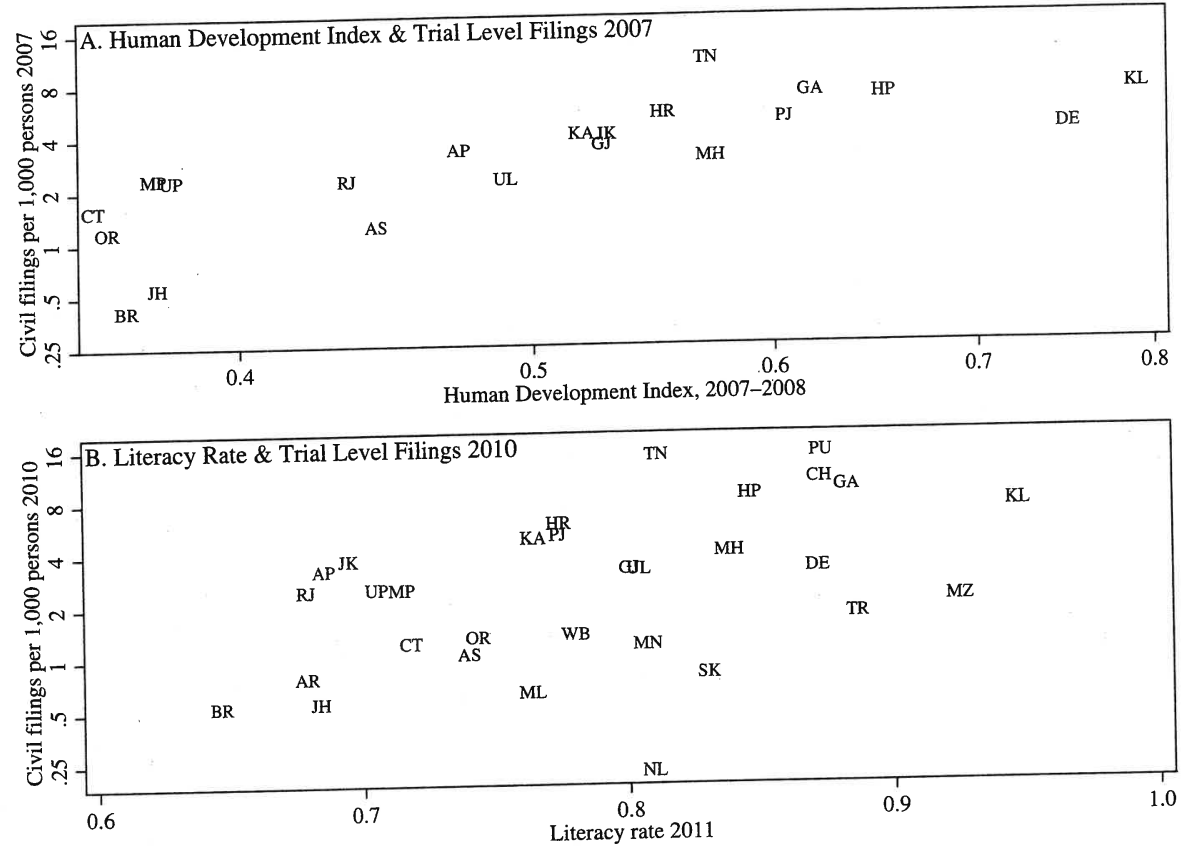

Note: State abbreviations are in Table 2. The $\mathrm{x}$ - and $\mathrm{y}$-axis scales are in logs. Sources: Per Capita Net Income supra note 82. INDIA Census 2001, supra note 96; India CENSUs 2011, supra note 77; India Human Development Report 2011, supra note 85.

Figures 1, 3, and 4. We exploited Figure 6's evidence that High Court data are useful proxies for the relation between the mass of filings and economic well-being by using the 1964-1983 High Court data to assess this connection over a longer period of time. To conserve space, Figure 7 reports the filings per capita-GDP relation for four years, spaced five years apart: 1967 (Figure 7.A), 1972 (Figure 7.B), 1977 (Figure 7.C), and 1982 (Figure 7.D). The y-axes are filings per 1,000 persons and the $\mathrm{x}$-axes are GDP per capita in current year rupees.

The data confirm the pattern for the 2005-2010 data. A strong, statistically significant association between filings per capita and GDP per capita persists throughout the years. The pattern is less visible in Figure 7.A because in 1967 the Delhi High Court's jurisdiction included the area that later became the State of Himachal Pradesh in 1971. The Delhi High Court area's relative leap in prosperity from 1967 to 1972 (shown by comparing the $\mathrm{x}$-axes values for Delhi in Figures 7.A and 7.B) is likely due to the carving out of the relatively poorer Himachal Pradesh area as a state with its own High Court. Himachal Pradesh's ("HP" in Figures 7.B, 7.C, and 7.D) lower pros- 
Figure 6: High Court Civil Filings Per Capita AND GDP Per Capita: Six-Year Averages, 2005-2010

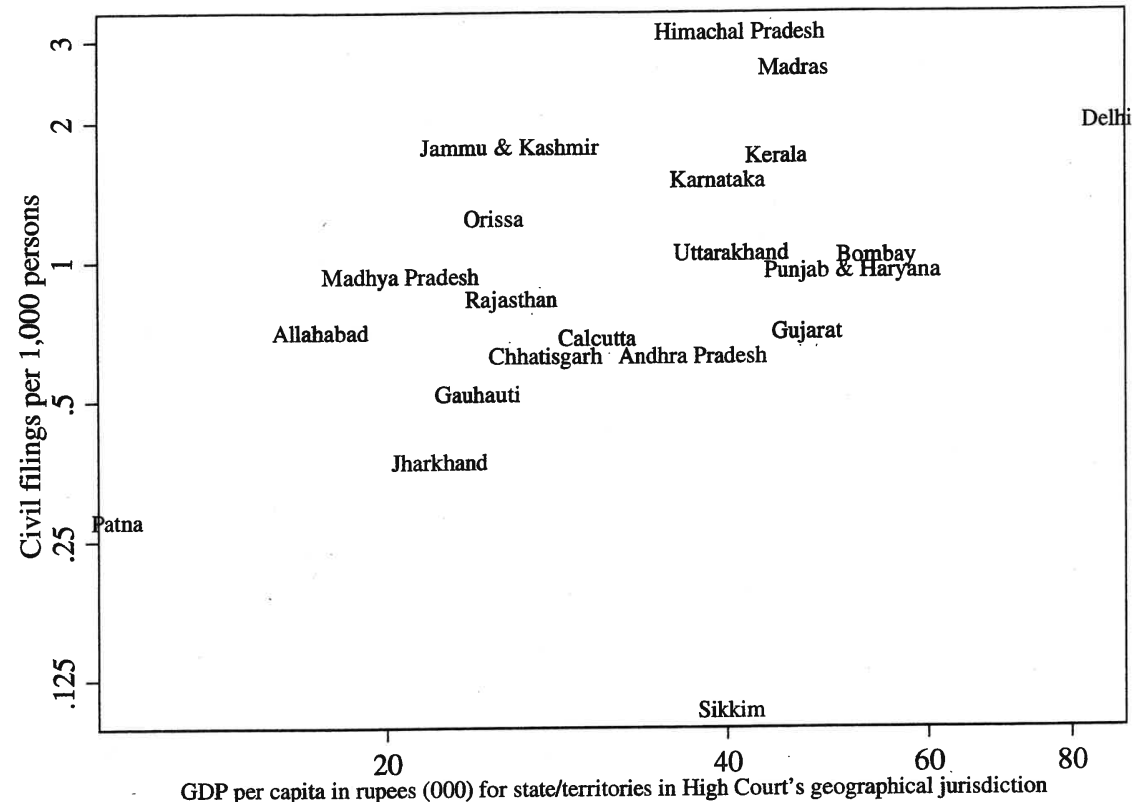

Note: The $\mathrm{x}$ - and $\mathrm{y}$-axis scales are in logs. Sources: Per Capita Net Income, supra note 82; INDIA Census 2001, supra note 96; India Census 2011, supra note 77; INDia Human Development REPORT 2011, supra note 85.

perity can be seen in the 1972,1977 , and 1982 data. Thus, Delhi proper was likely the most prosperous High Court geographical area, even in 1967. This effect is confirmed by inspection of figures (not shown here) for the years prior to and after 1972. In each year for which we have data, Delhi's prosperity relative to other High Court areas is similar to that in 1967 for 1970 and earlier years, and similar to that in 1972 for 1973 and later years. ${ }^{105}$ Carving out Himachal Pradesh was a milestone event in terms of the Delhi High Court area's relative prosperity.

Gauhauti is a persistently low-filing High Court in Figure 7. Gauhauti has jurisdiction over India's seven northeastern states, all of which have small populations, except for Assam. ${ }^{106}$ Yet, Figure 6 shows that in recent years Gauhauti's relation between filings and economic well-being is consistent with the general pattern of other High Courts. The area covered by the Gauhauti High Court moved from

105. The year of the Himachal Pradesh High Court's creation, 1971, was a transitional year that we did not explore.

106. See supra Tables $1,2$. 
Figure 7: High Court Civil Filings per 1,000 Persons AND GDP, FIVE-Year INTERVALS
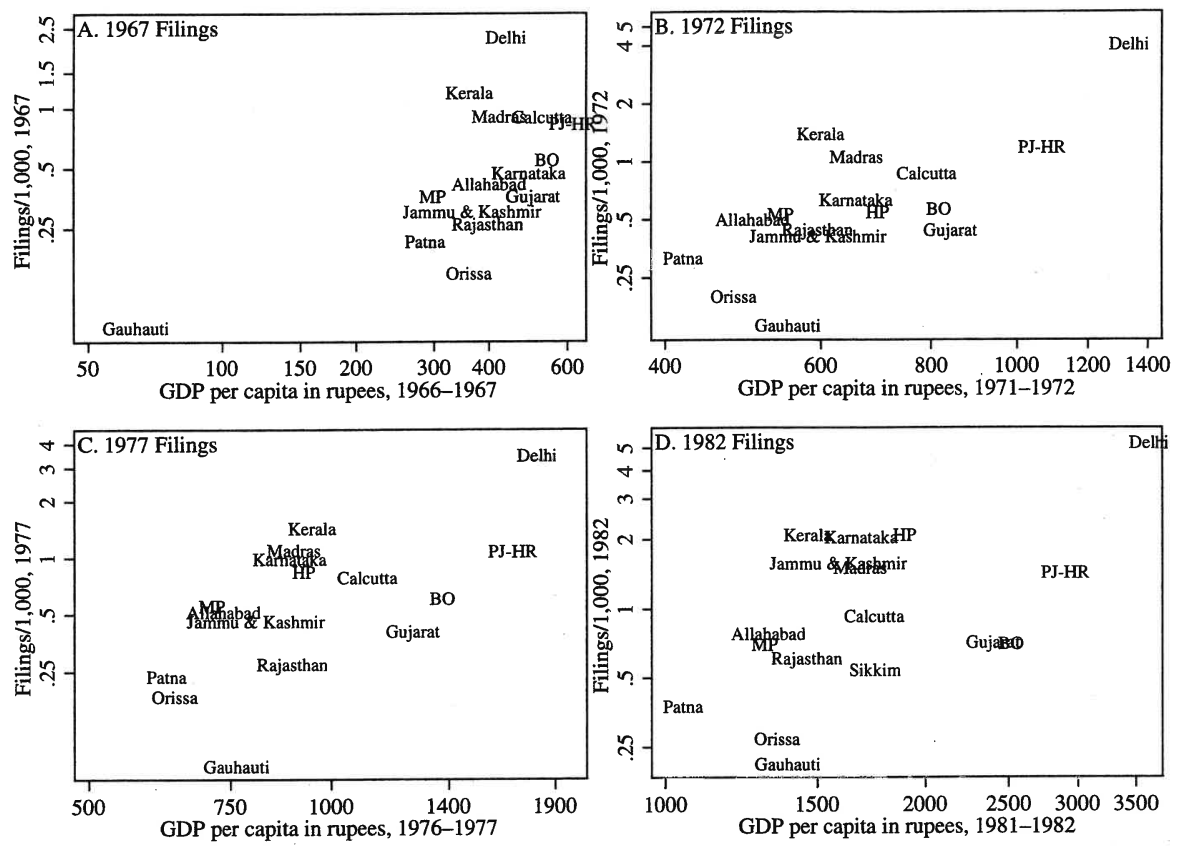

Note: $\mathrm{BO}=$ Bombay, HP=Himachal Pradesh, MP=Madhya Pradesh, PJ-HR=Punjab \& Haryana. GDP amounts are based on fiscal years beginning April 1 and ending March 31. Himachal Pradesh High Court was established in 1971. Sikkim became a state in 1975. GDP data for Sikkim for 1976-1977 were missing in the Central Statistical Organization (CSO) source. The xand y-axis scales are in logs. Sources: Per Capita Net Income, supra note 82; INDIA CENsus 2001, supra note 96; INDIA Census 2011, supra note 77; INDIA HuMAN DeVElopment REPORT 2011, supra note 85.

low filings per capita in the 1980 s, to a filings rate consistent with the mainstream by the 2005-2010 period. 107 By 1972, its GDP per capita was greater than or not materially different from that of several other High Court areas, a pattern that persists in the most recent time period. ${ }^{108}$ Gauhauti may be a within-state instance of improved relative economic well-being over time leading to increased and more mainstream relative civil filings rates.

Delhi, India's National Capital Territory, has a persistently high outlying High Court filing rate in Figure 7. In his six-country study, Professor Clark noted that high development is associated with a country's capital region. ${ }^{109}$ His data showed that the countries' capital

107. But in 1969, its civil filings rate exceeded that of the Orissa and Patna (Bihar) High Court areas. See supra Tables 1, 2.

108. See supra Figure 6.

109. See Clark, supra note 22, at 557; see also Figures 6, 7. 
regions showed higher litigation rates than did other areas. ${ }^{110}$ The Delhi High Court data are consistent with his predictions about a country's capital region.

Delhi's relative filing rates in the lower courts ${ }^{111}$ are not subject to this straightforward explanation. Our data show that filing rates in Delhi's lower courts have been lower than those of several other courts, such as Chandigarh and Goa, both of which are more prosperous than Delhi. ${ }^{112}$ When Chandigarh and Goa are grouped with other areas for purposes of High Court jurisdiction (Punjab \& Haryana and Bombay, respectively), their economic prosperity relative to Delhi is diluted; they fall below Delhi in prosperity and, at the High Court level, Delhi's High Court filing rate exceeds their rates. ${ }^{113}$,

Economic prosperity, however, as measured by GDP per capita, can be only a partial explanation for Delhi's varying rank in filings across High Courts and lower courts. ${ }^{114}$ Nevertheless, several areas that are less prosperous than Delhi (Himachal Pradesh, Kerala, Puducherry, and Tamil Nadu) have higher civil filing rates in lower courts. Kerala's higher filing rate may be a function of its well-being exceeding that of Delhi based on the HDI, or based on non-GDP measures of economic prosperity. ${ }^{115}$ Kerala has by far the highest life expectancy and lowest infant mortality of states for which the data are reported. ${ }^{116}$ And consumer household expenditures in Kerala exceed those of other major states. ${ }^{117}$ At the High Court level, Himachal Pradesh's filing rate exceeds Delhi's in recent years even though its GDP per capita is less than half that of Delhi. ${ }^{118}$ Note, however, that by the HDI well-being measure, Himachal Pradesh is not as far behind Delhi as by the GDP measure. ${ }^{119}$ By at least one measure of

\footnotetext{
110. See Clark, supra note 22, at 559-61.

111. See supra Table 2; Figures 6, 7.

112. See supra Figure 3.

113. See supra Figure 6.

114. See supra Figure 3.

115. See supra Figure 5, Table 2.

116. Ministry of LAW \& Justice, supra note 67.

117. See Nat'l Sample Survey Office, Gov't of India, Level and Pattern of ConSUMER EXPENDITURE 2009-2010, at 22-23 (2011) (showing Kerala ranking first in rural consumer expenditures and second to Goa in urban consumer expenditures); see also NAT'L Sample Survey Org., Gov't of India, Household Consumer Expenditure in India, 2007-2008, at 13 (2010) (showing Kerala ranking first of major states in rural and urban consumer expenditures). Kerala's stronger performance as measured by household expenditures may relate to its high percentage of households receiving inflows from remittances outside of India. See Devesh Kapur, Diaspora, Development, and Democracy: The Domestic ImPACT OF INTERNATIONAL Migration FROM INDiA 115-19 (2010).

118. See supra Table 2.

119. See supra Table 2, Figure 5.
} 
poverty, Himachal Pradesh's poverty rate is about two-thirds of Delhi's. ${ }^{120}$

\section{Within-State Changes in Litigation Rates and Prosperity}

Parts V.A.1 and V.A.3 show cross-sectional associations between civil filings and prosperity across states. A natural, further question is whether filings and prosperity move in the same direction within a state over time. If filings and GDP growth were to move in opposite directions within a state, the possibility exists that the interstate filings-GDP association is an artifact of unobserved factors that vary across states, which are simply correlated with the factor we observe, GDP. Within a state, movement in the same direction cannot be attributable to unobserved factors that differ across states because the state being analyzed is held constant. Analyzing within-state change accounts for unobserved factors in a state that do not vary over time. The 1977 and 2010 lower court state-level filings and GDP data allow us to observe the association between changes in civil filing rates and changes in economic prosperity for two widely separated points in time within India's states. If the association between filings and prosperity exists, states with increased GDP should show increased filings, and those states with greater change in GDP between the two years should show greater increases in filings per capita.

Figure 8 shows India's nominal GDP growth over time. ${ }^{121}$ Notwithstanding substantial inflation, real growth has been impressive. The rapid increase is usually attributed to economic reforms of the 1990s, which included liberalized trade and a reduction in the size of the public sector. ${ }^{122}$ In the GDP measures used in this subpart, we adjusted rupees so that higher GDP values represent real, not nominal increases. $^{123}$ Analysis of change over time should also account for the

120. Guruswamy \& Singh, supra note 32 , at 285 tbl.1.

121. Growth consistent with Figure 8 emerges in the figures above by, for example, comparing the $\mathrm{x}$-axis scales in Figures 6 and 7. Both use nominal rupees and the high end of Figure 6, which covers 2005-2010, requires a value of about 80,000 rupees per capita for the $\mathrm{x}$-axis. The high end of Figure 7.C, which covers 1977, requires a value of between 1,400 and 1,900 rupees per capita, with most states concentrated below 1,000 rupees.

122. See, e.g., Devesh Kapur, Explaining Democratic Durability and Economic Performance: The Role of India's Institutions, in PUBlic Institutions IN INDIA, supra note 75, at 29; Ashok Kotwal et al., Economic Liberalization and Indian Economic Growth: What's the Evidence?, 49 J. ECON. Literature 1152, 1194 (2011) ("The sustained growth that we have seen since the mid-1990s would clearly not have been possible without the liberalizing reforms of 1991."). Kotwal and his colleagues also stated that "some aspects of the earlier economic regime played a positive role in the pattern of development later." Id.

123. To adjust for inflation, we used the year-to-year changes in the December wholesale price index available in a report entitled Month-Wise Variation in Inflation Annual Rate in India (1981-2011). These data are available at IndiaStat, see supra note 65. 
fact that the Census was conducted once every ten years. For example, using the 1981 Census to account for states' 1977 populations overstates their populations and therefore understates 1977 per capita filings. Similarly, using the 2011 Census for 2010 populations slightly understates 2010 per capita filings. In this Subpart, we used linear interpolation to estimate 1977 and 2010 populations, which were then used to compute per capita filings and GDP. We similarly adjusted 1977 GDP because the data we used in the cross-section analyses were 1980 GDP per capita.

FIGURE 8: INDIA's GDP, 1950-2010

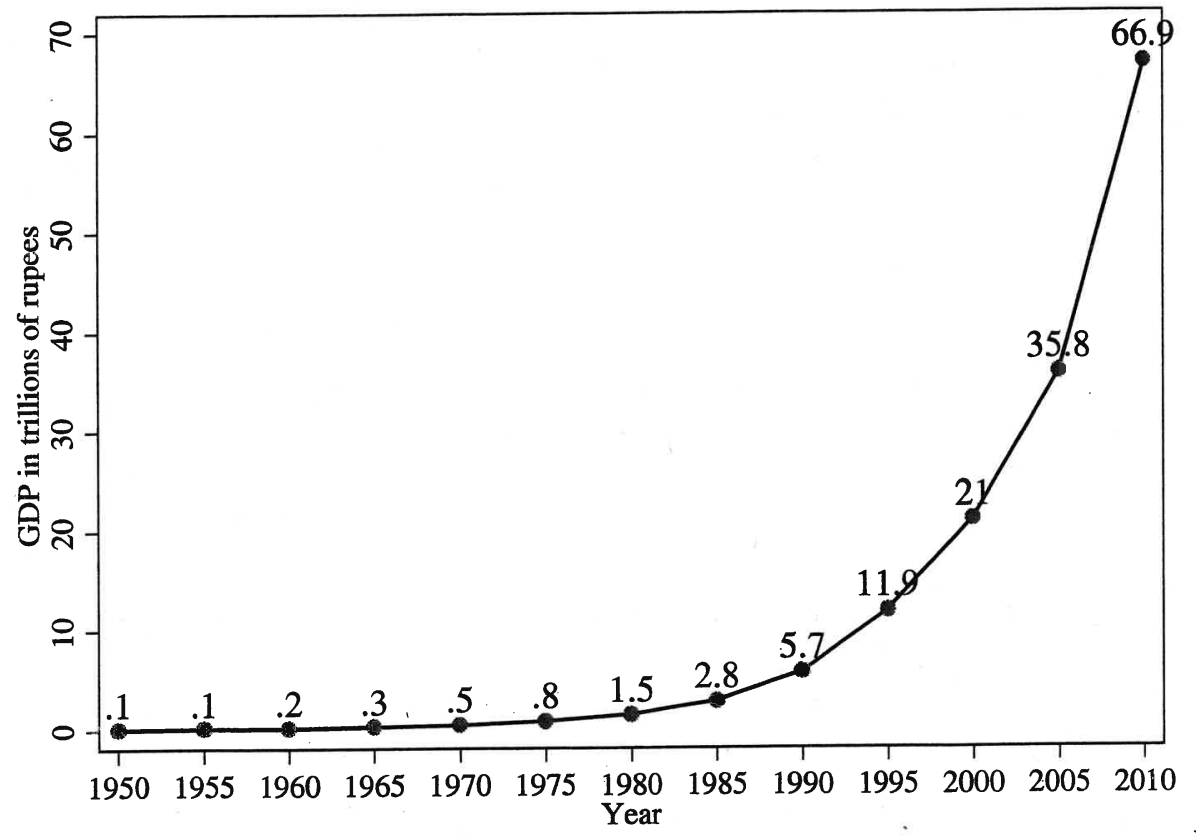

Sources: Central Statistical Organization, India Ministry of Statistics \& Programme Implementation, Gov't. of India ("CSO"), Nat'1 Accounts Statistics Back Series 1950-1951 to 1999-2000 (2007); CSO, Nat'l Accounts Statistics 2011; CSO, Nat'l Accounts Statistics 2012.

For each state, we computed the difference in filings per capita by subtracting the 1977 filings per capita from the 2010 filings per capita. Real GDP growth over time varies across states. By using GDP at the state level and using within-state change in its growth over time, we can partly control for varying state growth rates. We therefore computed each state's change in GDP by subtracting the state's GDP in inflation-adjusted 1980 rupees $^{124}$ from the state's GDP in 2010. Figure

124. The 1977 state-level GDP we used was reported in 1980 rupees. 
9 shows the outcome. A sharp drop in the reported number of Delhi's lower court filings from 2009 to 2010 led us to report two values for Delhi, one based on 2010 filings, the same end point year used for all other states, and one based on 2009 filings (with an accompanying shift to 2009 GDP data). The 2009 values are labeled "DE (2009)" in Figures 9 and 10 below.

\section{Figure 9: The Change in Civil Filings as a Function of Change in GDP, By State, 1977-2010}

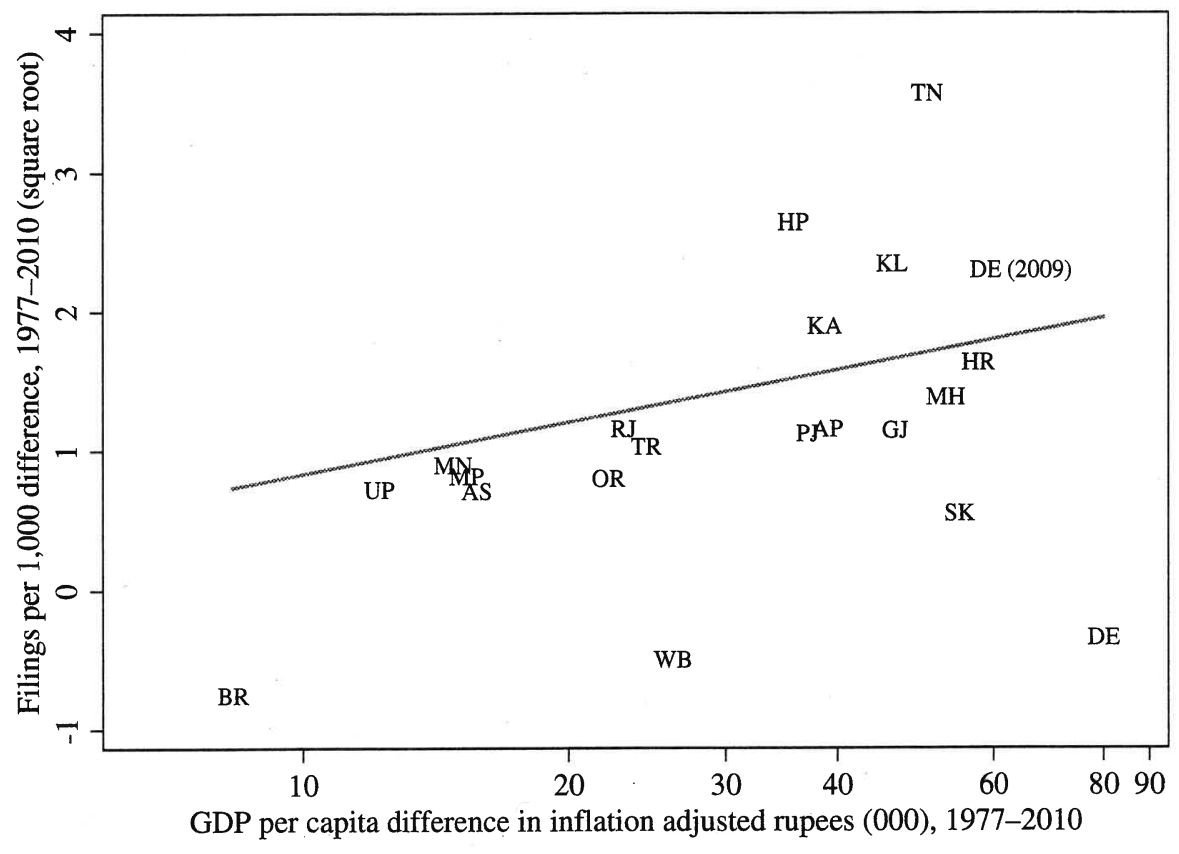

Note: The figure shows the difference in filings per capita in lower courts from 1977 to 2010 as a function of the difference in GDP per capita for the same two years. Some states lacked data for both years and are not included. Filings per capita are shown on the y-axis using a variancereducing square root transformation. For the three states with a filing decrease, the square root of the absolute value of the decrease was taken and then the sign restored to its negative status. Two data points are reported for Delhi due to the dramatic decline in filings reported from 2009 to 2010. Sources: Per Capita Net Income, supra note 82; India Census 2001, supra note 96; India Census 2011, supra note 77; India Human Development Report 2011, supra note 85.

Figure 9 shows two interesting results. First, all states show increased real GDP per capita (all $x$-axis values are positive) and all but three states, Bihar, Delhi (using 2010 data), and West Bengal, show increased filings per capita. A strong tendency therefore exists for GDP and filings to move in the same direction within a state. Second, the flow of the data points from lower left to upper right shows that the size of the filing increase within a state is associated with the size 
[Vol. 62:247

of the GDP increase in the state. States with larger GDP per capita growth had larger filing per capita increases. The state with the largest filing decrease, Bihar, had the smallest GDP increase. In a regression model of the change in filings per capita as a function of the change in GDP per capita, the coefficient for the change in GDP per capita is large and statistically significant. ${ }^{125}$ The line shown in Figure 9 is the predicted line from a regression model. Comparing 1977 with recent years, other than 2010 , did not produce materially different results.

Does the within-state association between filing changes and GDP changes exist over a time period shorter than the thirty-three years between 1977 and 2010? To explore this, we repeated the within-state change analysis in Figure 9, but replaced 1977 with the earliest recent year for which we have data, 2005, and computed filing and GDP differences between that year and 2010 .

Figure 10 presents the results, which differ strikingly from those in Figure 9. Real economic growth persists in all states; all of the real GDP differences on the $x$-axis are positive. But the changes in filings differ. Eleven of thirty states for which we have data for both years (all those falling below the horizontal " 0 " line in the figure) show reduced filings per capita in 2010 compared to 2005. Several others show no material increase. Our data allow us to compute the differences in filings within states for 146 state-year observations from 2005 to 2010 , seventy-one of which showed a decline in filings in the subsequent year. So, despite broad economic growth, about half of the possible state-year observations showed declining civil filings per capita. In an analysis not shown here, the same pattern exists for High Court cases from 2005 to $2010 .{ }^{126}$ Figure 8 shows that the period 2005-2010 was one of substantial GDP growth for India. Large GDP growth was

125. Heteroskedasticity (nonconstant variance of subpopulations in a data set) was apparent in a scatterplot of the change in filings per capita as a function of the change in GDP per capita. The presence of heteroskedasticity can invalidate the assumption of homogeneous variance underlying regression analysis. See MYERs, supra note 101, at 168-69. We therefore employed weighted least squares regression, see id., with weighting based on the difference in GDP per capita $(\log )$. Because the dependent variable benefitted from a square root transformation and had two negative values, we added a small constant to each observation to assure only positive values before the transformation. The regression model uses the 2010 Delhi data.

126. See sources cited supra note 95. Interestingly, there is substantial growth in Supreme Court civil filings during this same period (2005-2010). According to Annual Statements of the Supreme Court of India, in 2005, 22,117 civil cases were filed in the Supreme Court (if counted as the total number of civil special leave petitions (SLP), appeal, and writ petitions filed as admission matters in 2005); that number rose to 32,603 in 2010. However, this increase in filing in the Supreme Court likely has little to do with an increase in prosperity during this time period. Instead, this marked increase is more likely a sign that litigants increasingly view appeal to the Supreme Court favorably for other reasons. This may be because Supreme Court precedent is 
not accompanied by filings growth within many states. Thus, an association between GDP growth and filings growth had a reasonable opportunity to emerge, yet did not.

Figure 10: Change in Civil Filings as a Function of Change IN GDP, BY StATE, 2005-2010

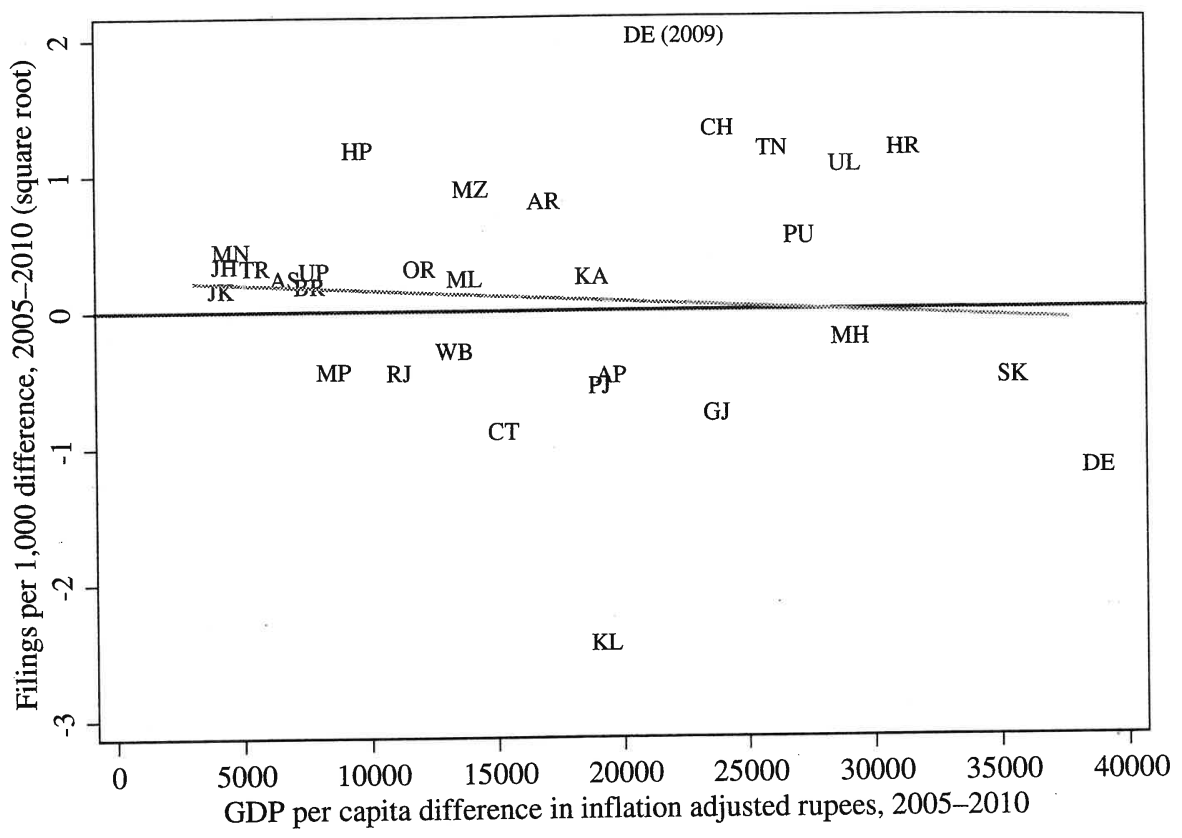

Note: The figure shows the change in filings per capita in lower courts from 2005 to 2010 as a function of the change in GDP per capita for the same years. For states with a filing decrease, the square root of the absolute value of the decrease was taken and then the sign restored to its negative status. Due to Mizoram's implausibly low filings reported in 2005, the figure uses the 2006 to 2010 differences for that state. Two data points are reported for Delhi due to the dramatic decline in filings reported from 2009 to 2010. Sources: Per Capita Net Income, supra note 82; India Census 2001, supra note 96; India Census 2011, supra note 77; INDIA Human DeVELOPMENT REPORT 2011, supra note 85.

Some of the more extreme changes from 2005 to 2010 may be artifacts of the particular years used. Kerala's large filing decrease in Figure 10 is sensitive to the choice of year because 2005 was a year of extraordinarily high reported filings for it compared to any subsequent year. ${ }^{127}$ This spike may lead to an overstatement of Kerala's 2005 filing rate and of the decline from 2005 to 2010. As already noted, Delhi's filings also fluctuated substantially in the $2005-2010$ pe-

becoming less clear, making appeal a more successful strategy, or because appeal is becoming a more favored tactic for delay.

127. Filings in 2005 were at least $69 \%$ higher than in any subsequent year. See infra Figure 10. 
[Vol. 62:247

riod. Mizoram's filings in 2005 were reported to be twenty-five, compared to 2,369 in 2010, and substantial variation also exists for Arunachal Pradesh. So the most extreme data points in Figure 10 are likely also the most questionable. The overall pattern, however, is not one of systematic increase. The sloping line in the figure is the line predicted by a regression model of filings change as a function of GDP change. The slope is nearly flat, statistically insignificant, and, if anything, shows a negative association between GDP change and filings change.

\section{Filings Rates and the Case Backlog}

Growing concern exists in India that people forego using the courts because of the large backlog of cases, ${ }^{128}$ which the Supreme Court has issued orders to address. ${ }^{129}$ It is thus possible that the absence of within-state association between changes in filing rates and changes in GDP in recent years could be associated with India's case backlog. That backlog has increased substantially over recent decades. In 1977 , the ratio of pending lower court civil cases to filings was 1.48 ; by 2010 it had grown to 1.88 , an increase of $27 \% .130$ The interstate associations using lower court and High Court data, and the within-state changes, as measured by the 2010 and 1977 differences, suggest that changes in GDP do influence filings. But that process may break down in a court system that processes cases insufficiently. Individuals, in greater numbers, may have responded to the expected delay by declining to file cases in the early twenty-first century. The absence of association in Figure 10 may be evidence of that process. We therefore analyzed in more detail the relation between filings and case backlog.

Figure 11 shows the relation between states' civil filings per capita and their civil case backlogs for each state for each year from 2005 to 2010. The data flow from upper left to lower right, suggesting that increasing backlog is associated with decreasing filings. The trend is highly statistically significant, with a correlation coefficient of -0.43

128. See Hazra \& Debroy, supra note 71 , at 17 ; see also Hazra \& Micevska, supra note 35 , at 149; Kasturi, supra note 63.

129. See, e.g., Ahmad v. State of Uttar Pradesh, A.I.R. 2012 S.C. 642 (Allahabad High Court) (India).

130. These clearance rates were calculated by dividing the number of civil pendency cases in $1977(1,369,752)$ by the number of civil cases disposed in that year $(923,978)$, and then doing the same for $2010(7,813,193$ by $4,148,609)$. The 2010 numbers come from High Court News (2010). The 1977 numbers are from the seventy-seventh Law Commission Report, which came out in 1978. LAw COMM'N OF INDIA, supra note 66. 
and a significance level of $\mathrm{p}=0.004 .{ }^{131}$ In recent years, therefore, the individual state-year observations show a strong negative association between backlog and filings.

\section{Figure 11: Relation Between Lower Court Civil Filings} and Civil Case Backlog, 2005-2010

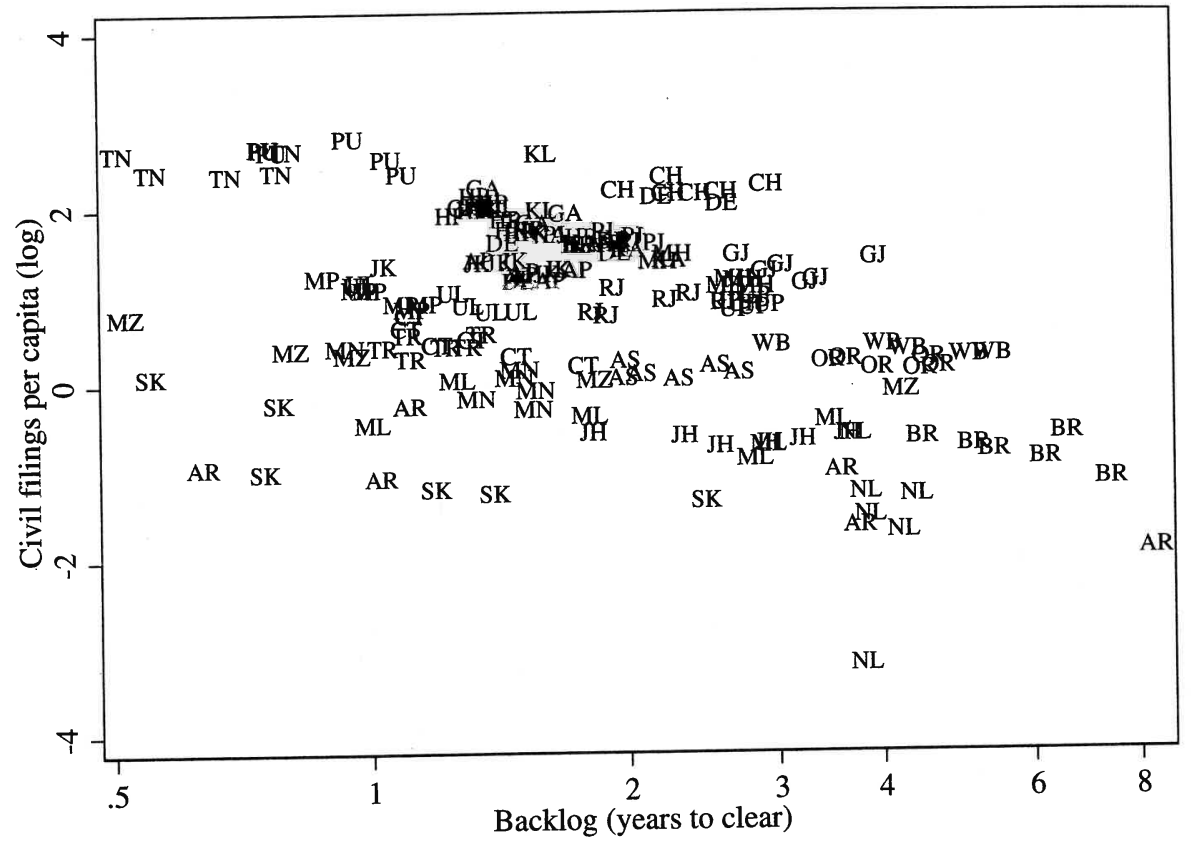

Note: The figure shows civil filings per capita in lower courts from 2005 to 2010 as a function of the backlog for the same years. The relation is shown for each state for each year. Due to Mizoram's implausibly low filings reported in 2005, the figure includes data for Mizoram only for the years 2006-2010. The $\mathrm{x}$-axis scale is in logs. Source: Per Capita Net Income, supra note 82; INDIA Census 2001, supra note 96; INDIA Census 2011, supra note 77; INDIA HuMAN DeveloPMENT REPORT 2011, supra note 85.

As in the case of the filings-GDP relation, a natural, further inquiry is the relation between filings and backlog within states over time. If the negative association between filings and backlog suggested by Figure 11 persists within states, those states with increased backlogs over time should show decreased filings over time. Figure 12 shows the filing change-backlog change relation in the same manner that Figure 10 shows the filing change-GDP change relation. Figure 12, unlike

131. This significance level is based on a regression with filings as the dependent variable, backlog as the explanatory variable, and standard errors clustered by state. If the estimate of the coefficient of an explanatory variable is more than two standard errors away from zero, it is referred to as statistically significant. Gelman \& HILL, supra note 99, at 42. Two standard errors correspond to a p-value of 0.05 . 
Figure 10, shows a noticeable association. In other words, increasing backlogs are associated with decreasing filings.

Figure 12: Change in Civil Filings as a Function of Change in BAcklog, By State, 2005-2010

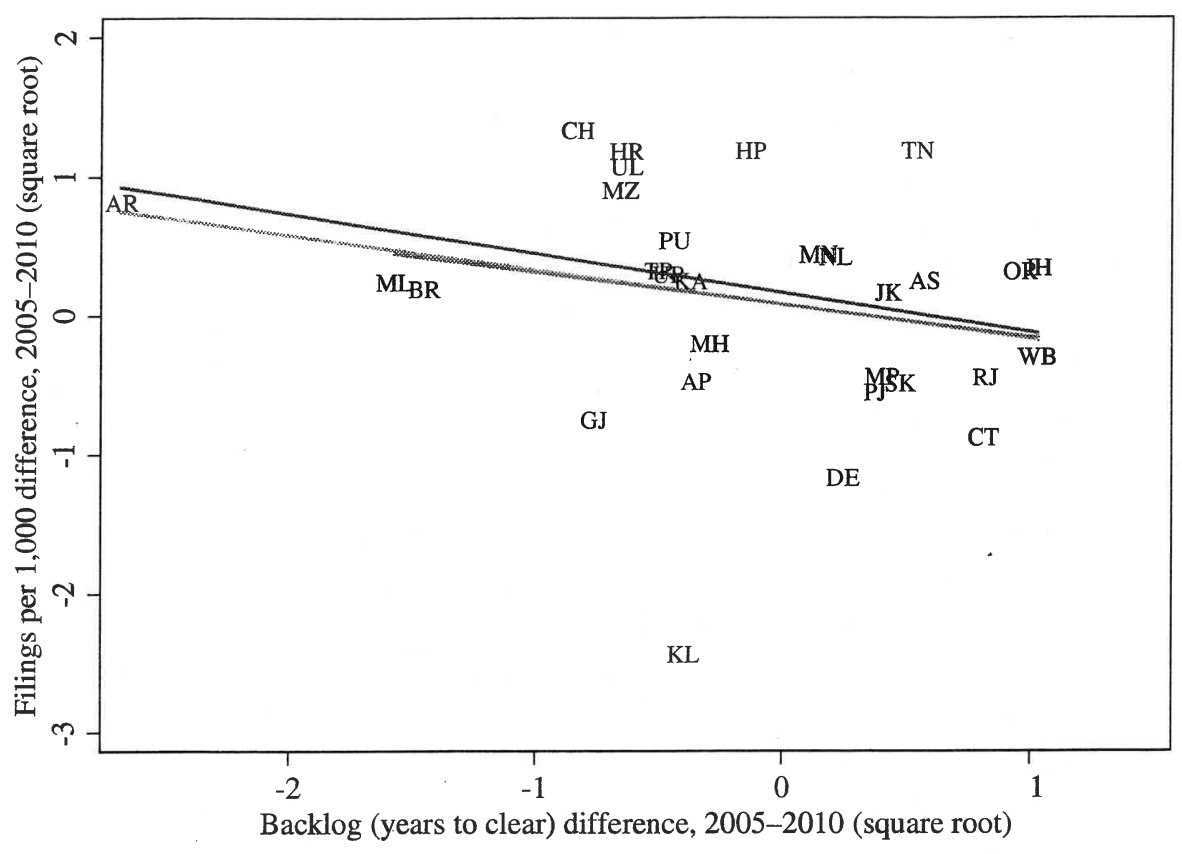

Note: The figure shows the change in filings per capita in lower courts from 2005 to 2010 as a function of the change in the backlog for the same years. For states with a filing or backlog decrease, the square root of the absolute value of the decrease was taken and then the sign restored to its negative status. Due to Mizoram's implausibly low filings reported in 2005, the figure uses the 2006 to 2010 differences for that state. The lines in the figure are predicted values from regressions that account for outliers as described in the text. Sources: India Census 2001, supra note 96; INDIA CENSUs 2011, supra note 77.

The lines in Figure 12 represent the predicted values from three regression models. The uppermost line shows the predicted change in filings if Kerala (KL), an outlier with respect to the change in filings, is excluded. The shortest line, barely distinct from the longer line adjacent to it, shows the predicted change in filings if Arunachal Pradesh (AR), an outlier with respect to backlog reduction, is excluded. The remaining line includes all states. The significance of the relation varies depending on the treatment of outliers, but it is consistently significant at the $\mathrm{p}<0.10$ or 0.05 levels. ${ }^{132}$ The figure shows that the relation

132. In a regression model with robust standard errors that includes all thirty states in the figure, the significance of the filings change-backlog change association is $p=0.029$. If one excludes Kerala and Arunachal Pradesh, the significance level is $\mathrm{p}=0.065$. If one excludes only 
is consistently negative regardless of outlier treatment. Comparing Figure 12's noticeable trend with Figure 10's absence of relation suggests that backlog variation has recently had a greater influence on filing change than has GDP variation.

\section{B. Regression Results}

Part V.A assessed influences on filings separately from one another and suggested associations between filings and each of the following: (1) GDP; (2) population density; (3) the HDI; and (4) case backlog. In recent years, however, change in GDP had no association with change in filings, as shown in Figure 10. To further assess the relations between civil filings and the other factors, we employed regression models in which the rate of civil filings per capita is the dependent variable. Preliminary inspection of the data, as suggested by several of our figures, ${ }^{133}$ indicated that transformations of variables were needed, ${ }^{134}$ so the models use logarithmic transforms for continuous variables other than the HDI. The explanatory variables are GDP per capita (log); population density (log); the HDI; and the backlog, measured as years to clear $(\log )$. We added to the models dummy variables for the years 2006-2010, with 2005 serving as the reference category. These dummy variables help account for unobserved characteristics in each year. Because we observed the same geographic units-states-repeatedly over time, we cluster the standard errors by state. Table 3 reports the regression results. The regression results both confirm and illuminate the bivariate results in Part IV.A. We discuss each of the major effects separately.

Kerala, the significance level is $\mathrm{p}=0.012$. If one excludes only Arunachal Pradesh, the significance level is greater than $p=0.166$. By including only Kerala but not Arunachal Pradesh is the significance level greater than 0.10 . In a robust regression model that automatically assigns less weight to outlying values but includes all of them, the significance level is $p=0.098$.

133. Note that in all figures in which the volume of filings (in contrast to the change in filings over time within a state) is represented on the y-axis, the filings are reported in logs.

134. See, e.g., Sanford Weisberg, Applied Linear Regression 148-50 (3d ed. 2005); Theodore Eisenberg \& Martin T. Wells, The Significant Association Between Punitive and Compensatory Damages in Blockbuster Cases: A Methodological Primer, 3 J. Empirical Legal Stud. 175, 179-81 (2006). 
TABle 3: Regression Models of Civil Litigation FILING RATES

\begin{tabular}{|c|c|c|c|c|c|c|c|}
\hline & (1) & $(2)$ & (3) & $(4)$ & $(5)$ & (6) & (7) \\
\hline & \multicolumn{7}{|c|}{ Dependent variable $=$ civil filings per 1,000 persons $(\log )$} \\
\hline$\overline{\mathrm{HDI}}$ & & $\begin{array}{r}6.085^{*} \\
(1.079)\end{array}$ & & $\begin{array}{r}4.156^{*} \\
(0.704)\end{array}$ & & $\begin{array}{r}3.478^{*} \\
(0.756)\end{array}$ & \\
\hline Population density (log) & $\begin{array}{r}0.320^{+} \\
(0.141)\end{array}$ & $\begin{array}{c}-0.288^{*} \\
(0.098)\end{array}$ & $\begin{array}{c}-0.166^{\#} \\
(0.087)\end{array}$ & $\begin{array}{c}-0.271^{*} \\
(0.077)\end{array}$ & $\begin{array}{c}0.401^{*} \\
(0.114)\end{array}$ & $\begin{array}{c}-0.130 \\
(0.090)\end{array}$ & $\begin{array}{c}-0.017 \\
(0.097)\end{array}$ \\
\hline State GDP per capita $(\log )$ & $\begin{array}{c}0.957^{*} \\
(0.306)\end{array}$ & $(0.228)$ & $\begin{array}{c}1.345^{*} \\
(0.205)\end{array}$ & $\begin{array}{c}0.594^{*} \\
(0.232)\end{array}$ & $\begin{array}{c}0.600^{+} \\
(0.173)\end{array}$ & $\begin{array}{c}0.421^{+} \\
(0.193)\end{array}$ & $0.992^{*}$ \\
\hline 2006 dummy & $\begin{array}{c}0.006 \\
(0.169)\end{array}$ & $\begin{array}{r}-0.093^{\prime \prime} \\
(0.052)\end{array}$ & $\begin{array}{c}-0.230^{*} \\
(0.057)\end{array}$ & $\begin{array}{c}-0.154^{+} \\
(0.061)\end{array}$ & $\begin{array}{c}-0.222^{*} \\
(0.078)\end{array}$ & $\begin{array}{c}-0.175^{*} \\
(0.052)\end{array}$ & $\begin{array}{c}-0.241^{*} \\
(0.049)\end{array}$ \\
\hline 2007 dummy & $\begin{array}{c}-0.151 \\
(0.209)\end{array}$ & $\begin{array}{c}-0.128^{*} \\
(0.045)\end{array}$ & $\begin{array}{c}-0.490^{*} \\
(0.078)\end{array}$ & $\begin{array}{c}-0.294^{*} \\
(0.079)\end{array}$ & $\begin{array}{c}-0.218 \\
(0.132)\end{array}$ & $\begin{array}{c}-0.237^{*} \\
(0.073)\end{array}$ & $\begin{array}{c}-0.384^{*} \\
(0.071)\end{array}$ \\
\hline 2008 dummy & $\begin{array}{c}-0.261 \\
(0.220)\end{array}$ & $\begin{array}{c}-0.072 \\
(0.048)\end{array}$ & $\begin{array}{c}-0.623^{*} \\
(0.109)\end{array}$ & $\begin{array}{c}-0.319^{*} \\
(0.102)\end{array}$ & $\begin{array}{c}-0.177 \\
(0.163)\end{array}$ & $\begin{array}{c}-0.219^{+} \\
(0.104)\end{array}$ & $\begin{array}{c}-0.444^{*} \\
(0.103)\end{array}$ \\
\hline 2009 dummy & $\begin{array}{c}-0.399 \\
(0.261)\end{array}$ & $\begin{array}{c}-0.108 \\
(0.077)\end{array}$ & $\begin{array}{c}-0.818^{*} \\
(0.153)\end{array}$ & $\begin{array}{c}-0.424^{*} \\
(0.145)\end{array}$ & $\begin{array}{c}-0.293 \\
(0.175)\end{array}$ & $\begin{array}{c}-0.282^{+} \\
(0.129)\end{array}$ & $\begin{array}{c}-0.572^{*} \\
(0.121)\end{array}$ \\
\hline 2010 dummy & $\begin{array}{c}-0.326 \\
(0.320)\end{array}$ & $\begin{array}{c}-0.079 \\
(0.054)\end{array}$ & $\begin{array}{c}-0.958^{*} \\
(0.151)\end{array}$ & $\begin{array}{c}-0.471^{*} \\
(0.149)\end{array}$ & $\begin{array}{l}-0.335 \\
(0.199)\end{array}$ & $\begin{array}{c}-0.331^{+} \\
(0.140)\end{array}$ & $\begin{array}{c}-0.695^{*} \\
(0.135)\end{array}$ \\
\hline Backlog (years to clear $(\log )$ ) & & & & & $\begin{array}{c}-0.902^{*} \\
(0.177)\end{array}$ & $\begin{array}{c}-0.596^{*} \\
(0.152)\end{array}$ & $\begin{array}{c}-0.711^{*} \\
(0.145)\end{array}$ \\
\hline Constant & $\begin{array}{r}-10.90^{*} \\
(2.800)\end{array}$ & $\begin{array}{c}-0.194 \\
(0.404)\end{array}$ & $\begin{array}{r}-11.40^{*} \\
(2.114)\end{array}$ & $\begin{array}{r}-5.306^{*} \\
(1.757)\end{array}$ & $\begin{array}{c}-7.056^{*} \\
(2.166)\end{array}$ & $\begin{array}{c}-3.684^{+} \\
(1.456)\end{array}$ & $\begin{array}{r}-8.277^{*} \\
(1.814)\end{array}$ \\
\hline Obser & 181 & 128 & 128 & 128 & 181 & 128 & 128 \\
\hline R-squared & 0.411 & 0.662 & 0.582 & 0.709 & 0.597 & 0.795 & 0.709 \\
\hline
\end{tabular}

\section{The GDP and Backlog Effects}

Focusing first on model (1), the coefficient for GDP per capita is substantial and statistically significant. So, while accounting for population density, GDP is positively associated with filings per capita. This association persists in model (5), the only other model reported that used the full set of state-years. Model (5) differs from model (1) only in that it adds the backlog as an explanatory variable. The GDP coefficient remains significant in all other models as well, which are included to account for the effect of the HDI and backlog. The backlog's large and statistically significant coefficients in models (5) to (7) confirm the filings-backlog association suggested by Figure 11.

\section{The GDP-Backlog Relation}

The backlog's significance persists in models that include GDP as an explanatory variable. This suggests that the backlog's effect on filings is not solely due to GDP influencing the backlog through GDP's direct effect on filings, which increases the backlog. If it were, the backlog-filings association should not persist when GDP per capita is 
accounted for simultaneously with backlog. The association between GDP and the backlog would introduce substantial multicollinearity into the model, which would deflate the importance of one or both variables. ${ }^{135}$ Yet both variables remain statistically significant and a test of multicollinearity shows it not to be a substantial concern. ${ }^{136}$ In recent years, the case backlog's effect is increasing in importance over GDP's effect, as suggested by comparing the relations between changes in each to changes in filings, illustrated in Figures 10 and 12. Furthermore, in regression models (not reported here) of the withinstate change in filings per capita from 2005 to 2010 as a function of the changes in GDP per capita and changes in case backlog for that period, we found some evidence of a negative association between filings change and backlog change and no evidence of a positive association between filings change and GDP change. In recent years, changing backlog, more than changing GDP, has driven within-state changes in filings.

\section{The HDI Effect}

Figure 5 suggests that noneconomic well-being, as represented by life expectancy and education included in the HDI, is associated with litigation rates. We therefore included the HDI as an explanatory variable in three regression models: (2), (4), and (6). Because the HDI is not available for several states, fewer observations are available for those models than for models (1), (3), and (5). ${ }^{137}$ Note, however, that the states excluded for want of HDI data are uniformly small, with a total population of about sixteen million people, which constitutes less than $2 \%$ of India's population.

Model (2) is the same as model (1) except that the HDI replaces GDP per capita as an explanatory variable. To assure a common sample of states for purposes of comparing the effects of the HDI and GDP, model (3) repeats model (1), but limits the sample to those states included in model (2). So models (2) and (3) use the same sam-

135. There is some evidence of reduced significance among the variables. The coefficient for GDP is much smaller in model (5) than in model (1). And, in a model not reported here, the coefficient on backlog is larger in absolute value (-1.06) in a model that is the same as model (1) except with backlog replacing GDP. Thus, both GDP and backlog are of reduced influence when appearing in models together rather than separately-they are nontrivially correlated.

136. The average Variance Inflation Factor (VIF) for model (5) is 1.62, suggesting no substantial presence of multicollinearity. See Alan C. Acock, A Gentle Introduction to Stata 263 (3d ed. 2010). GDP has a VIF of 1.56 , suggesting that $1 / 1.56$, or $64 \%$ of the variance in GDP is available after adjusting for the other predictors. Id. Backlog has a VIF of 1.15, suggesting that multicollinearity is even less of a concern with respect to it.

137. See supra Table 2. 
[Vol. 62:247

ple of states and differ only in that model (2) uses the HDI and model (3) uses GDP per capita. As measured by the proportion of the variance in the dependent variable explained by the model (the r-squared row in Table 3), model (2) fits the data substantially better than model (3). ${ }^{138}$ Model (4), again using the reduced sample, includes both the HDI and GDP, and both variables remain statistically significant. The model with both variables fits the data better than the models with only one of them (models (2) and (3)), with another improvement in fitting the data as measured by the proportion of variance explained. Multicollinearity is a greater concern here because the HDI includes an express economic component, which should correlate with GDP. A test of multicollinearity, however, suggests that it is not a substantial concern. ${ }^{139}$ Thus, while GDP per capita is an important factor in explaining litigation rates, noneconomic well-being also has a substantial role to play. If one had to choose between the HDI and GDP, the HDI produces superior models. ${ }^{140}$ In models not reported here, the HDI outperforms literacy when they are included in models separately and the coefficient on literacy is not significant when they are included in models together.

\section{The Population Density Effect .}

The population density coefficient varies across models. It is positive and significant in models (1) and (5), which include the states that lack HDI information. It is negative, however, in the models that exclude those states and is statistically significant in some of those models but not in others. This variability is likely because the states lacking HDI information include many with the most extreme population densities. The six least densely populated states lack HDI information. ${ }^{141}$ Chandigarh and Puducherry lack HDI information and are

138. Another way to compare models using the same data, the same dependent variable, but differing explanatory variables is the root mean squared error, which measures how far a model's predicted values differ on average from observed values. The root mean squared error in model (3) is 0.56 compared to 0.50 in model (2) and 0.47 in model (4). Therefore, the models that include the HDI outperform the models without this measure as well. The Akaike information criterion also indicates that models that include the HDI fit the data better than those without it.

139. The average VIF for explanatory variables in this model is 2.13 , with GDP having a VIF of 3.18. Note that the size of the GDP coefficient in model (4) is smaller than its size in model (3), suggesting that some of GDP's explanatory power is absorbed in the HDI. Similarly, the size of the HDI coefficient is smaller in model (4) than in model (2). Nor is multicollinearity a substantial concern in model (6), with an average VIF of 2.14 .

140. In a model using standardized coefficients, the HDI coefficient is $54 \%$ larger than the GDP coefficient. For information about a factor analysis that includes the HDI and GDP, see infra note 151.

141. See supra Table 2. 
two of the three most densely populated areas. So, including the HDI as an explanatory variable substantially reduces the variation in population density across states in the models. Because population density is significant when the full sample of states is available (in the models that do not include the HDI), population density cannot be ruled out as a significant influence on litigation rates, notwithstanding its insignificance in models (6) and (7) and its marginal significance in model (3).

One concern about regression models that include the backlog as an explanatory variable is the presence of endogeneity, or reciprocal causation, ${ }^{142}$ which makes ordinary least squares regression results questionable. ${ }^{143}$ The backlog may influence civil filings, but the volume of past filings and the past backlog clearly influence the backlog. To address this concern, we explored simultaneous equations models that simultaneously model civil filings and the backlog and allow the number of filings in a prior year to influence the backlog. ${ }^{144}$ The results do not materially differ from those reported here. ${ }^{145}$

\section{CONClusion}

The positive association between civil litigation and well-being should be reasonably interpreted. It does not imply that filing more lawsuits will increase societal well-being. ${ }^{146}$ Causation almost certainly runs in the opposite direction, with increased well-being leading to more lawsuits. The positive association is consistent with the law and development theorists' view that the modernization of a country increases reliance on formal institutions. It is also consistent with the

142. Judith D. Singer \& John B. Willett, Applied Longitudinal Data Analysis: Modeling Change and Event Occurrence 177 (2003). Ginsburg \& Hoetker address an endogeneity issue in their Japan study, with their primary concern being that the number of lawyers and judges was not exogenous to the amount of litigation. See Ginsburg \& Hoetker, supra note 23, at 46 tbl.2. Hazra \& Micevska address this issue with respect to backlogs in India. See Hazra \& Micevska, supra note 35, at 151 tbl.7.3.

143. See, e.g., StataCorp LP, Stata Base Reference Manual: Release 12, at 1659 (2011).

144. The structural equations in those models are the same as those in Table 3. The equation modeling the backlog uses one-year-lagged filings and the one-year-lagged backlog as explanatory variables.

145. Serial correlation in the dependent variable does exist and we have run autoregressive conditional heteroskedasticity models, commonly known as ARCH models, as a further check. They yield results consistent with those in Table 3 . In models with random effects for states, the coefficients for HDI and backlog remain highly statistically significant and the coefficient for GDP per capita is marginally significant. For an effort to address similar correlation in backlog models, see Hazra \& Micevska, supra note 35, at 150-52.

146. At the individual level, however, the outcome of a lawsuit may increase personal wellbeing. 
[Vol. 62:247

overlapping account that states with higher GDPs have more transactions per capita. Thus, even if the litigation rate per transaction is constant over time, there will be more disputes per capita and therefore more lawsuits per capita. ${ }^{147}$

An economic boom could conceivably decrease filing because prosperity may lead to more "forgiving behavior," given that the costs of going to court may be higher than simply just engaging in other economic activity. ${ }^{148}$ Our results suggest that the factors underlying increased litigation rates outweigh this potential effect. Alternatively, times of economic decline might also be associated with increasing litigation rates. ${ }^{149}$ For example, a declining economy is associated with more debt collection and bankruptcy filings, ${ }^{150}$ which might dwarf the negative effect of economic decline on filings. Given the consistent economic growth in India shown in Figure 8, we cannot assess how a declining economy may impact litigation rates in India.

To our knowledge, the influence of noneconomic well-being on litigation rates has not heretofore been assessed. The fact that higher litigation rates are associated with Indian states with higher HDI indices suggests that people are more likely to use the courts to resolve disputes when they are economically, socially, and physically better off. Higher GDP is also correlated with higher litigation rates, but less so than the HDI.

The HDI's explanatory superiority is likely due to it having an economic component, income per capita, and a noneconomic component, including education level and life expectancy. ${ }^{151}$ Our findings may suggest that part of the increase in litigation rates in higher HDI states

147. See Tom Ginsburg \& Glenn Hoetker, The Effects of Liberalization on Litigation: Notes Toward a Theory in the Context of Japan, 8 WAsh. U. Global Stud. L. Rev. 303, 304 (2009). 148. See id.

149. See, e.g., Clark, supra note 22, at 564; Ginsburg \& Hoetker, supra note 23, at 51 (reporting that Japanese prefecture level filings increased when prefectural income declined from the prior year).

150. Van Loon \& Langerwerk, supra note 51, at 285.

151. The HDI outperforms models in which its use as an explanatory variable is replaced by both GDP per capita and literacy rates. In models that include both the HDI and literacy rates as explanatory variables, the coefficient for literacy rates is insignificant. We have also explored models that include state-level poverty rates, which are also significantly correlated with litigation rates. Models using the HDI outperform those using poverty rates in its place. In models that include both the HDI and poverty rates as explanatory variables, the coefficient for literacy rates is insignificant. In models that included the HDI, literacy rates, and poverty rates, multicollinearity leads to unreliable coefficient estimates. We used the poverty rates reported in the study by Guruswamy and Singh. See Guruswamy \& Singh, supra note 32, at 285 tbl.1. Factor analysis (principal factor) suggests that only one principal factor is at work among these explanatory variables, with a much less important second factor also at work. The HDI loads most strongly on the first factor and the poverty rate loads most strongly on the second factor. 
is driven by individuals with increased education or life expectancy. These individuals may file claims in personal disputes or small commercial disputes. The implications for those who are concerned about the fact that many Indians lack access to justice and courts is that simply improving the courts or macroeconomic growth are not the most important factors in ensuring that people have access to the courts. Indeed, guaranteeing access to justice, which includes providing individuals with a realistic chance to vindicate rights through litigation, may require governments to ensure economic opportunity and social rights to individuals. GDP growth alone does not assure all individuals a realistic opportunity to vindicate their rights.

Another, somewhat surprising result is that filings in recent years do not increase with increasing prosperity. ${ }^{152}$ The leveling-off theory referred to in Part II might be considered as a source of this result. If India has reached a plateau, however, its filings are leveling off at levels well below filings in more prosperous countries. Despite India's impressive recent growth, its overall prosperity remains at modest levels with respect to basic measures such as GDP per capita and the HDI. One mechanism for the plateau being reached also seems absent. Sarat and Grossman argued that as society becomes more developed, courts become specialized so that the generalist courts lack the expertise to resolve disputes. Although India has some recent movement in the area of specialized dispute resolution tribunals, that movement is likely insufficient to explain the severing of the relation between economic growth and litigation growth. ${ }^{153}$

A more likely explanation for the absence of association between GDP change and filing change in recent years is a high and increasing case backlog. ${ }^{154}$ Increased backlog was significantly associated with reduced filings per capita. This finding resonates with qualitative beliefs about the backlog's effect, and also with an earlier effort to quantify the effect. ${ }^{155}$ This explanation also has intuitive appeal. Figure 11 and Table 2 show that backlogs in many states exceed two years, even assuming no new filings, and the 1977 data establish that backlogs have increased over time in relation to filings. It would not be surprising if, at some point, potential litigants turn away from courts for dispute resolution as a result. India may have reached that point.

India's challenge is not that too many cases are filed, but that too few are timely adjudicated. Its litigation rate, by world standards, is

152. See supra Figure 10.

153. See supra notes $86-87$ and accompanying text.

154. See supra Table 3, Figures 11, 12.

155. See Kasturi, supra note 63. 
not high. The judiciary, though in increasing demand as the country prospers, could threaten India's prosperity if it cannot accommodate demands for its services. India may thus provide a test of theories that a well-functioning court system is critical to economic growth. ${ }^{156}$ Its lower court system continues to be regarded as dysfunctional and we provide evidence that the backlogs now discourage use of the courts. ${ }^{157}$ It should be noted that the backlogs may be caused not principally by slow case processing by judges, but by the fact that there may not be enough courts allotted or because of the large number of judicial vacancies that currently exist. In addition to the increasing backlog in Indian courts, other factors that have not been tested in this Article could also account for decreasing litigation rates, such as corruption, which, among other problems, leads to a lack of predictability in the system. Additionally, many judges, especially in the lower courts, lack proper infrastructure and instruments, such as computers or typewriters, to undertake their work. Despite this, the country has undergone substantial growth. Whether that growth can continue will yield important information about the need for a wellfunctioning judiciary to promote well-being.

India's civil filings story has implications beyond its borders. The anti-litigation movement in the U.S. and elsewhere is built in part on characterizing litigation as evidence of social malfunction. Evidence from India and elsewhere that increased litigation often accompanies improved human well-being should be considered when evaluating the social implications of the amount of litigation.

156. See, e.g., Hazra \& Debroy, supra note 71, at 30; TrANSPARENCY InT'L, Global CoRruPTION RePORT 2007, at xxi-xxii (Diana Rodriguez \& Linda Ehrichs eds., 2007) ("[A] corrupt judiciary ... diminishes trade, economic growth and human development ....").

157. It has been noted that extreme delays provide incentives to bring invalid claims as well as disincentives to bring valid claims. Carl Baar, Delays in the Administration of Justice, in JudICIAL REFoRMS In INDIA, supra note 35, at 119, 124. 